\title{
Gene Delivery with Organic Electronic Biomaterials
}

\author{
Kathryn Frances Anne Clancy ${ }^{\mathrm{a}, \mathrm{b}}$, John George Hardy ${ }^{* \mathrm{~b}, \mathrm{c}}$ \\ ${ }^{a}$ Department McGill Biomedical Engineering Department, Duff Medical Building, 3775 rue University, \\ Montreal, Quebec, H3A 2B4, Canada; ${ }^{b}$ Department of Chemistry, Faraday Building, Lancaster \\ University, Lancaster, LAI 4YB, United Kingdom; ${ }^{c}$ Materials Science Institute, Lancaster University, \\ Lancaster, LA1 4YW, United Kingdom
}

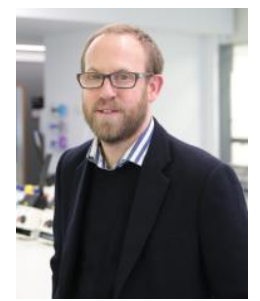

\begin{abstract}
Gene therapy may be capable of treating a variety of diseases, a prerequisite of which is the successful delivery of polynucleic acids (e.g., DNA, RNA) to a patient's cells. Delivery can be achieved technologically (e.g., using electroporation), using viruses (natural gene delivery vectors) or non-viral vectors (e.g., lipids, nanoparticles, polymers). This article aims to give the reader an overview of the use of organic electronic materials (i.e., fullerenes, graphenes and conjugated polymers) as non-viral gene delivery vectors.
\end{abstract}

Keywords: organic electronics, carbon nanotubes, fullerene, graphene, conjugated polymer, gene delivery, gene therapy, biodegradable.

\section{INTRODUCTION}

Gene delivery has become a well-established field of science [1-4]. While viruses are Nature's protein-based gene delivery vectors, various other vectors have been investigated for their ability to deliver deoxyribonucleic acids (DNA) or ribonucleic acids (RNA), including lipids, nanoparticles, polymers (e.g. polyethyleneimine (PEI) or polyamidoamine (PAMAM) dendrimers, depicted in Fig. 1), and the bountiful literature is discussed in some interesting reviews [1-4]. Gene therapy was first approved for use by the European Commission (a viral gene vector, Glybera ${ }^{\circledR}$, to treat lipoprotein lipase deficiency that can cause pancreatitis) [5-8], and recent clinical trials for the use of gene therapy to treat a variety of conditions including leukemia, myeloma and Parkinson's disease have been promising [9-13].

Organic electronic materials (OEMs) are of interest for technical and biomedical applications [14-20]. OEMs are typically comprised of fullerenes (bucky balls or nanotubes), graphene/graphene oxide, or conjugated polymers (e.g. polyaniline, polypyrrole or polythiophene), examples of which are depicted in Fig. 2. Importantly, derivatives of these are commercially available allowing researchers to tailor the properties of the OEMs either through chemical modification or the generation of composites, with a view to their use for technical applications (e.g. diodes, solar cells, transistors) and medical applications (e.g., drug delivery, electrodes for the nervous system, theranostics) [14-20]. The optical properties (e.g., high fluorescence yield, high photostability) of organic electronic nanoparticles allows them to be imaged, and chemical modification of the nanoparticles facilitates complex formation with their therapeutic payload and targeting to specific cells, potentially yielding particles capable of simultaneous diagnostic, imaging and therapeutic activity [21].

*Address correspondence to this author at the Department of Chemistry and Materials Science Institute, Faraday Building, Faculty of Science and Technology, Lancaster University, Lancaster, Lancashire, LA1 4YB, United Kindgom; Tel: +441524595080, E-mail: j.g.hardy@lancaster.ac.uk
The focus of this article is gene delivery systems that are based on nanoscale OEMs, highlighting examples of each class of nanoscale OEMs in a systematic fashion to give the reader an overview of the topic.

\section{FULLERENE-BASED NON-VIRAL VECTORS FOR GENE DELIVERY}

Fullerenes are carbon-based nanomaterials, that are either spherical (bucky balls) or ellipsoids/tubes (commonly known as carbon nanotubes) depicted in Fig. 2, and for which the Nobel Prize in Chemistry was awarded to Curl, Kroto and Smalley in 1996.

\subsection{Bucky balls}

Unmodified bucky balls are hydrophobic rendering them poorly soluble in aqueous media, and interesting fundamental studies show that they interact with amphiphilic cell membranes prior to uptake [22-25], they are relatively quickly cleared from blood (accumulating in the liver and spleen [25]), and they exhibit dose-dependent toxicity in vivo (low toxicity at low concentrations in mice, and high toxicity at high concentrations with potential for mutagenic/teratogenic activity) [25].

Bucky balls functionalized with hydrophilic anionic/cationic species (Fig. 3) improves their solubility in water and renders them capable of forming complexes with calf thymus DNA as demonstrated by Nakamura and coworkers [26]. Bucky balls displaying four amines transfect vector plasmids (pGreen LANTERN-1) into fibroblast-like monkey kidney tissue cells, COS-1 cells [26]; and interestingly, the presence of serum plasma may assist dispersion of bucky ball-DNA/RNA complexes and their effective uptake [27]. Various derivatives of bucky balls have been described [28-32], including bucky ball derivatives displaying polymers such as PAMAM dendrimers that were capable of delivering DNA to the 
MCF-7 human-derived breast cancer cell line or humanderived cervical cancer HeLa cells [33], and bucky ball derivatives displaying polyethyleneimine (PEI) and poly(ethylene glycol) (PEG) that were capable of delivering DNA to human embryonic kidney (HEK293) cells [34]. An elegant diversity-oriented study showed that tetra(piperazino)fullerene epoxide (Fig. 3) was more effective and less toxic than the commercially available lipid-based transfection reagent Lipofectin ${ }^{\circledR}$ [35], and this was also demonstrated to effectively deliver the plasmids (encoding GFP) in vivo in the ICR strain of mice [36], and siRNA to EGFP-overexpressing C57BL/6 mice [37].

\subsection{Carbon nanotubes}

Studies of the biological fates of carbon nanotubes with different dimensions (i.e. diameter and length) are important, particularly for uncovering differences between singlewalled nanotubes (SWNTs) and multi-walled nanotubes (MWNTs). The fates of intact MWNTs (with diameters of 20-30 nm and lengths of up to $1000 \mathrm{nM}$ ) were compared to shorter oxidized nanotubes [38]; both intact and oxidised nanotubes were taken up by a combination of endocytosis and phagocytosis; and the intact nanotubes were present in both intracellular and extracellular domains whereas the oxidised versions were detected preferentially in intracellular vesicles with limited amounts in extravesicular cytoplasm or brain parenchymal areas. The surface chemistry appeared to play a role in the inflammatory response to the nanotubes implanted in the brain of mice; with astrocyte and microglia activation in the vicinity of the injections, with slightly greater inflammatory response to the oxidized than the intact nanotubes after 30 days [38]. MWNTs (with diameters of $\geq$ $20 \mathrm{~nm}$ ) were shown to induce p53-dependent responses in fetal development, moving across the blood-placenta barrier, restricting the development of foetuses and inducing brain deformity (i.e. teratogenicity), whereas smaller MWNTs (with diameters of $8 \mathrm{~nm}$ ) showed markedly less fetotoxicity and SWNTs showed no fetotoxicity relative to controls, suggesting that MWNTs damaged the DNA, thereby inducing cell cycle arrest and apoptosis [39]. MWNTs (with diameters of 20-50 nm) used to transfect DNA into Escherichia coli were shown to damage the DNA (i.e. they were genotoxic), which resulted in mutation of the bacteria [40], and the results of these studies have given useful insight that will hopefully inform future research [41].

Akin to unmodified bucky balls, unmodified carbon nanotubes are hydrophobic which makes surface functionalization with hydrophilic moieties capable of forming electrostatic complexes with DNA/RNA commonplace [42, 43]. Nanotube functionalization via covalent and non-covalent methodologies [43, 44] is straightforward, and cell-specific targeting of nanotubes can be achieved with cell-specific ligands [43-45], or the application of external stimuli such as magnetic fields to magnetic derivatives of carbon nanotubes [46]. Interestingly, amine [47] or carboxylate [48] functionalized nanotubes can be degraded enzymatically with horseradish peroxidase or fluids that mimic the phagolysosomal fluid of macrophages has encouraged the development of carbon nanotube-based gene delivery vectors, and is discussed in excellent reviews [49-52].

Molecular modeling and experimental data indicates that complex mixture of supramolecular interactions, including electrostatic, hydrogen bonding, $\pi$-stacking and van der Waals interactions play a role in the binding of nanotubes to DNA [53-61], and RNA [57, 62-65]. An elegant study including computational simulations and in vitro cell culture studies with keratinocytes highlighted the role of the electronic structure of nanotubes on RNA binding and delivery, with metallic SWNTs delivering siRNA into the nucleus of keratinocytes, whereas semiconducting SWNTs transported siRNA only to the cytoplasm [66]. Interestingly, hydrophobic interactions that facilitate DNA binding to anionic carboxy-functionalized MWNTs yield complexes that were shown to transfect the DNA more effectively into Nile Tilapia (Oreochromis niloticus) spermatogonial stem cells than either electroporation or Lipofectamine ${ }^{\circledR} 2000$ [67]. It is noteworthy that while cationic lipids can be effective non-viral vectors for gene delivery $[68,69]$, their formulation with nanotubes may increase the amount of DNA carried in otherwise equivalent formulations, improve their stability in the presence of serum (in analogy to the effect observed for bucky balls [27]) and improve their transfection efficiencies relative to commercially available Lipofectamine ${ }^{\circledR} 2000$ [70]. Complexes of SWNTs, PEGylated phospholipids, poly(allyamine hydrochloride) and siRNA were capable of targeting the mutant K-Ras gene in human pancreatic carcinoma epithelial-like PANC-1 cells, and diminishing gene expression levels of mutant K-Ras mRNA by ca. $30 \%$ in vitro [71]. Complexes of amine functionalized SWNTs with cationic liposomes and siRNA (capable of targeting the luciferase gene in human lung cancer A549-Luc cells) were effective in silencing the luciferase gene, and a synergistic pro-apoptotic effect was obtained when delivering siRNA (siPLK1) and doxorubicin from the complexes in A549 cells in vitro [72], and moreover in Calu6 tumor xenografts [73]. Furthermore, complexes of nanotubes with cationic lipids and glyceraldehyde 3-phosphate dehydrogenase siRNA function in vivo in $\mathrm{CD}-1$ mice, effectively mediating gene silencing [74].

Functionalization of nanotubes with naturally occurring amines (e.g. spermidine, spermine) yields bottle brush-like structures that are analogous to dendrimers with high binding affinities due to multivalency effects [75-80]. If nanoparticle-DNA or nanoparticle-RNA complexes are stuck in endocytic vesicles (which fuse with early endosomes, mature into lysozomes, and then degrade biomolecules trapped inside), treatment with chloroquine assists their escape from the vesicles [57, 76]. However, the generation of stimuli-responsive nanotubes potentially offers additional control of the location/time of payload delivery, and as such attaching cationic moieties via bioreducible disulphide bonds [81-83] facilitates the delivery of their therapeutic payload 
siRNA (that suppresses tumor activity through interfering with MDM2 protein binding to p53 protein [84]), to breast carcinoma B-CAP-37 cells [85]. Complexes of aminefunctionalized SWNTs and DNA effectively delivered the oncogene suppressor p53 gene to human breast cancer MCF7 cells [85]; complexes of other amine-functionalized SWNTs have successfully transfected plasmid DNA (encoding the vp7 gene) to fish (grass carp) in vivo [86-89]. Interesting studies directed towards diminishing brain damage after stroke and traumatic brain injury by silencing caspase-3 expression (activation of which results in cell death) via carbon nanotube-mediated delivery of caspase-3 siRNA was shown to reduce neurodegeneration and promote functional preservation before and after focal ischemic damage in vivo in rats [47].

Functionalization of nanotubes with synthetic polyamines (e.g. PEI $[90,91]$ or polyamidoamine (PAMAM) dendrimers $[92,93])$ is popular as the synthetic polyamines are effective non-viral gene delivery vectors, and conjugated to nanotubes they enable gene transfection both in vitro and in vivo, enabling transfection of microRNA regulating angiogenesis [94].

PEI-functionalized SWNTs delivered anti-luciferase siRNA into human lung cancer cell line H1299 (which expresses firefly luciferase), and were found to less effective than either PEI or Lipofectamine ${ }^{\circledR} 2000$ and more cytotoxic than either PEI or Lipofectamine ${ }^{\circledR} 2000$ [95]. Interestingly, analogously functionalized SWNTs [96] or MWNTs [97] effectively transfect DNA plasmids encoding luciferase into mouse neuroblastoma Neuro-2a cells in vitro, and for the SWNTs in vivo studies delivering the nanotube-DNA complexes via intravenous injection into the tail vein of rats showed the highest levels of transfection to the lungs [96].

First generation (G1) PAMAM-functionalized MWNTs were shown to transfect the pGL3 vector (encoding luciferase) into HeLa cervical cancer cells and the monkey kidney fibroblast-like COS-7 cell line, with greater efficiency and lower toxicity than the nanotubes, G1 PAMAM (1.4 kDa) or $25 \mathrm{kDa}$ PEI alone [98]; by comparison, fourth generation (G4) PAMAM-functionalized MWNTs were more effective at transfection of DNA (encoding GFP) into the HeLa cells than the nanotubes or PAMAM alone yet somewhat less effective than Lipofectamine ${ }^{\circledR}$ 2000, and importantly, G4 PAMAMfunctionalized nanotubes were less cytotoxic than either G4 PAMAM or Lipofectamine (®) 2000 [99]. An analogous study using first to third generation (G1-G3) PAMAMs showed that G2 was the optimal for transfection (nanotube-G2: 6.8 $\%$ vs nanotube-G1 $2.2 \%$ or nanotube-G3 $4.1 \%$ ), albeit slightly more toxic than the G1 derivative [100]. Functionalization of the surface of MWNTs with G1 or G2 PAMAMs facilitated the transfection of a fluorescently labelled siRNA [101, 102], whereas functionalization with G1 to G5 PAMAMs facilitated the transfection of antisense c-myc oligonucleotides into human breast cancer cells (MCF-7 and MDA-MB-435 cells) and human liver cancer HepG2 cells down regulating the expression of the C-Myc gene and protein, and in this case the G5-functionalized nanotubes were most effective [103]. Carbon nanohorns functionalized with G4 or G6 PAMAM were shown to be effective at delivering siRNA that diminished levels of house-keeping GAPDH mRNA or p42-MAPK mRNA in vitro [104].

Functionalization of nanotubes with ligands that target specific receptors displayed on cells is one method of targeting vectors to specific cell populations, for example folate-functionalization to target cancer cells that overexpress folate receptors [105]. Indeed, folatefunctionalized chitosan conjugated to MWNTs effectively transfected pEGFP DNA into the HeLa cervical cancer cells in vitro. Importantly, the nanotubes displayed dimensiondependent transfection efficiency and toxicity, with shorter nanotubes (100-400 $\mathrm{nm}$ in length and external diameters of $10-20 \mathrm{~nm}$ ) being the most effective at transfection yet also the most toxic, whereas longer nanotubes ( $800 \mathrm{~nm}$ to $3 \mu \mathrm{m}$ in length and external diameters of 10-20 nm) were somewhat less efficient but markedly less toxic. Furthermore, the surface functionalization of MWNTs (with folatefunctionalized chitosan) improves the transfection efficiency (of pEGFP DNA) to 1.5 times that of unfunctionalized MWNTs, and decreases their cytotoxicity relative to unfunctionalized MWNTs [106].

Aptamer-functionalized SWNTs enable targeted delivery of DNA/RNA to various cell lines. For example, SWNTs functionalized with 5 TR1 aptamers (targeting MUC1) enabled the delivery of Bcl-xL-specific short hairpin shRNA to MUC1 positive breast cancer cells in vitro [107]; likewise, SWNTs functionalized with AS1411 aptamers (targeting nucleolin receptors) enable the delivery of Bcl-xL-specific short hairpin shRNA to human gastric cancer AGS (+nucleolin) cells and achieve shRNA-mediated genesilencing strategy [108].

Peptide-functionalization of nanotubes can markedly improve their solubility in aqueous media, which may in certain cases (e.g. (-Lys-Trp-Lys-Gly-) $)_{7}$ ) also improve transfection ability [109,110]. Alternatively, functionalization of SWNTs with the tumor targeting NGR peptide (Cys-Asn-Gly-Arg-Cys) enabled the effective transfection of siRNA to human prostate cancer (PC-3) cells that induced severe apoptosis and suppressed proliferation of the cells in vitro, and moreover, in vivo in tumor-bearing mice [111]. Interestingly, complexes of plasmid DNA (encoding GFP) with estradiol functionalized MWNTs enhances their transfection efficacy towards cells that overexpress estrogen receptors over Lipofectamine ${ }^{\circledR} 2000$, both in vitro (to estrogen positive MCF-7 cells) and in vivo in rats [112].

The use of external stimuli such as light or magnetic fields may enable relatively high levels of spatiotemporal control of gene delivery. Indeed, complexes of SWNTs with cholesterol-functionalized PEI and pTP53 plasmid DNA enhanced apoptosis and necrosis of HeLa cells in vitro, and achieved a higher tumor-growth inhibition in vivo, when enhanced by near infrared (NIR) laser-mediated 
photothermal transfection (Fig. 4) [113]. This was demonstrated by a variety of studies. The pTP53 containing the p53 gene (a cancer suppressor gene that may induce tumor cell apoptosis and arrest the cell cycle at the G1/S phase) was used as the therapeutic plasmid DNA, optionally in combination with SWNTs with cholesterol-functionalized PEI attached. The population of HeLa cells treated with naked pTP53 increased in the G0/G1 (Quiescence/Growth) phase, and a slight decrease in the G2/M (Growth/Mitotic) phase. The cells treated with the complexes of DNA and functionalized SWNTs showed a small population increase in the G0/G1 phase, and a larger decrease in the G2/M phase which was pronounced when exposed to NIR laser irradiation ( $3 \mathrm{~W} \mathrm{~cm}-2,3 \mathrm{~min}$ ) to approximately the same as Lipofectamine ${ }^{\circledR} 2000$ (see histograms and graph bars of cell cycle in Figure $4 \mathrm{~A}$ and 4B, respectively). It was observed that the treatment with the complexes of DNA and functionalized SWNTs and NIR laser irradiation induced significantly more necrosis and apoptosis of the HeLa cells, when compared to treatment with pTP53, Lipofectamine ${ }^{\circledR}$ 2000, or the functionalized SWNTs in the absence of NIR irradiation (see bar charts for apoptosis/necrosis in Figure 4C and the results of flow cytometry studies in 4D). These results were confirmed by observing the nucleus morphology with Hoechst 33342 staining of the cells after $72 \mathrm{~h}$ with various treatments, where the highest number of bright dots (which indicate nucleus damage) was observed for cells after the treatment with the complexes of DNA and functionalized SWNTs and NIR laser irradiation (Figure 4E). Suggesting that SWNTs have promise for photothermal transfection that functions by increasing membrane permeability, facilitating photoactive chemicals to escape from endosomes by generating reactive oxygen species, and thereby promoting the release of therapeutic genes [113].

MWNTs displaying both magnetic iron oxide and radio labels (99mTc) enabled simultaneous magnetic resonance imaging (MRI) and single photon emission computed tomography (SPECT) as demonstrated in vivo in mice [114]. MWNTs coated with magnetite nanoparticles and mesoporous silica were shown to facilitate efficient loading and delivery of gentamicin, cytochrome $\mathrm{C}$ and siRNA to MC3T3-E1 cells in vitro, and imaging in vivo in mice [115, 116]. MWNTs in electric fields are known to amplify the electric field at their ends by a factor of 10-100 [117] which was used to permeabilize cell membranes in vitro in gram negative bacteria (Acidothiobacillus ferrooxidans) and NIH/3T3 cells $[117,118]$, and excitingly in vivo in mice via electromagnetic field-induced intracerebral delivery of plasmid DNA encoding the Bcl-2 gene using microwave radiation 8-12 GHz, $5 \mathrm{~W}, 20$ seconds [117].

\section{GRAPHENE-BASED NON-VIRAL VECTORS FOR GENE DELIVERY}

Graphene derivatives (Fig. 2) have the thickness of a single layer of graphite, and display interesting electronic, magnetic and optical properties and for which the Nobel Prize in Physics was awarded to Geim and Novoselov in
2010. Their properties are attractive for a number of applications [18, 119], and their degradability in vivo [120] makes them of particular interest for biomedical applications, as discussed in a number of recent reviews [121-126].

Akin to unmodified bucky balls, nanohorns and nanotubes, unmodified graphene is hydrophobic and insoluble in aqueous media, and it is frequently converted to the more hydrophilic graphene oxide (which is moderately soluble in aqueous media), and the hydrophobicity of graphene and graphene oxide enable interactions with the hydrophobic parts of DNA and RNA [53, 127]. Indeed, complexes of graphene oxide with either plasmid DNA (encoding GFP) or siRNA (targeting glyceraldehyde-3phosphate dehydrogenase, GAPDH) are capable of transfection of human-derived cervical cancer HeLa cells and human umbilical vein endothelial cells (HUVECs) in vitro [128].

Strategies for their functionalization are analogous to nanotubes, typically covalent/non-covalent functionalization with cationic moieties, and the functionalization of graphene derivatives with various low and high molecular weight cations has been reported in the literature. Complexes of graphene oxide functionalized with octaarginine with DNA plasmid (encoding GFP) capable of transfection of human embryonic kidney (HEK293) cells in vitro [129]; or indeed transfection of Cell death siRNA to MCF-7 breast cancer cells transfection in vitro [130]. Complexes of ethidium bromide functionalized graphene oxide with plasmid DNA (encoding GFP) were markedly less toxic than ethidium bromide, and more effective at transfection to human gastric adenocarcinoma AGS cells than complexes with Lipofectamine® 2000 in vitro [131].

The functionalization of graphene quantum dots with poly(L-lactide)-PEG diminished the cytotoxicity of the graphene and enhanced the photoluminescence of the graphene over a broad $\mathrm{pH}$ (useful for imaging) and the conjugation of both miRNA-21-targeting and survivintargeting agents improved the inhibition of cancer cell growth and apoptosis of cancer cells in vitro in HeLa cells [132]. Functionalization of graphene with poly(2dimethylamino)ethylmethacrylate (PDMAEMA) by bioreducible disulphide bonds enabled successful transfection of plasmid DNA (encoding luciferase) into monkey kidney fibroblast-like COS-7 cells and human liver cancer HepG2 cells in vitro [133]. Likewise, complexes of graphene oxide functionalized with PEG and PEI by bioreducible disulphide bonds enabled successful transfection of plasmid DNA (encoding GFP) into human prostate cancer PC3 cells in vitro, which could be further enhanced by photothermal excitation upon exposure to NIR laser irradiation [134].

A comparison of complexes of graphene oxide functionalized with PAMAMs, PEI or polypropyleneimine (PPI) with plasmid DNA (encoding GFP) showed the PEI conjugates to be the most effective at transfection to mouse neuroblastoma Neuro-2a cells than complexes with either PAMAM or PPI in vitro [135]. Consequently, functionalization of graphene with PEI derivatives is popular, with complexes of linear PEI, anionic carboxy- 
functionalized graphene oxide and plasmid DNA enables transfection to HeLa cells [119], although the complexes were prone to aggregation in the presence of serum. Replacement of the linear PEI with branched PEI enhanced the stability of their complexes with DNA in serum containing media, thereby enabling light-controlled delivery of DNA plasmids into the NIH3T3 fibroblast line and human prostate cancer PC-3 cells [136], and siRNA delivery to human mammary MDA-MB-435S melanocytes upon exposure to NIR laser irradiation [137].

Complexes of graphene oxide and PEI were capable of delivering siRNA (targeting the $\mathrm{C}-\mathrm{X}-\mathrm{C}$ chemokine receptor type 4 (CXCR4), siCXCR4) and suppressing gene expression and the metastatic potential of MDA-MB-231 cells in vitro [138]. Complexes of graphene oxide functionalized with PEI and PEG with plasmid-based Stat3 siRNA were effective at transfection and gene silencing of malignant melanoma B16 cells in vitro [139]. Interestingly, complexes of graphene oxide functionalized with PEI, PEG and chitosan with short hairpin shRNA were shown to be $\mathrm{pH}$ responsive (releasing their payload of doxorubicin and RNA at $\mathrm{pH}<6.5)$ and to successfully deliver their payload to human liver cancer HepG2 cells in vitro efficiently silencing ABCG2 expression and making the tumor cells more sensitive to the anticancer drug doxorubicin [140].

Excitingly, complexes of PEI-functionalized graphene oxide with mRNA (for reprogramming transcription factors) successfully generated rat and human induced pluripotent stem cells (iPSCs) from adult adipose tissue-derived fibroblasts (ADFs) in vitro in a gene integration-free fashion (Fig. 5) [141]. The upper panel of Fig. 5A depicts a schematic diagram of the procedure for the preparation of human iPSCs by means of PEI-functionalized graphene oxide-mediated mRNA delivery into human ADFs, whereas the lower panel of Fig. 5 depicts bright-field images of the human iPSCs derived from the human ADFs; the former formed early iPSC-like colonies (day 18), and mature iPSC clones appeared after mechanical picking (day 24). The pluripotent properties of the iPSC clones generated from human ADFs were confirmed by immunocytochemical analysis with the iPSCs being positive for Oct4 expression (Fig. 5B). Furthermore, the expression of the endogenous pluripotency marker genes in iPSC clones (stemness marker genes: SSEA-4, Lin28A, Rex1, Nanog, and TRA 1-60), were well expressed in the iPSCs (Fig. 5C) but not in control hADFs. Reprogramming into iPSCs is accompanied with demethylation of promoters of critical pluripotency genes. The degree of epigenetic reprogramming was analyzed by studying the methylation patterns of the promoter region of a key pluripotency gene, Nanog. Bisulfite genomic sequencing of a 299-bp large region of the Nanog promoter which contains eight $\mathrm{CpG}$ sites was carried out. Although $\mathrm{CpG}$ sites of ADFs were methylated, none or only one $\mathrm{CpG}$ site was methylated in the PEI-functionalized graphene oxide-mRNA treated iPSCs (Fig. 7D), demonstrating that the pluripotent potential of the PEI-functionalized graphene oxide-mRNA treated iPSCs was similar to that of ES cell lines [141].

Furthermore, embedding complexes of PEI-coated graphene particles and DNA (encoding VEGF165) inside injectable hydrogels enabled their delivery to the site of acute myocardial infarction in vivo in rats, resulting in a significant increase in myocardial capillary density and reduction in scarring in the injected infarct region, and thereby improved cardiac performance [142].

Complexes of graphene oxide functionalized with PAMAMs and PEG with plasmid-based antisense oligonucleotides capable of antagonizing microRNA function were more effective at transfection to human lung cancer A549 cells than complexes with either Lipofectamine ${ }^{\circledR} 2000$ or PAMAMs in vitro [143]. Complexes of graphene oxide functionalized with PAMAM with DNA plasmid (encoding GFP) capable of transfection of human-derived cervical cancer HeLa cells in vitro [144]. Complexes of carboxy-functionalized graphene, PAMAMs and plasmid DNA (encoding GFP) effectively transfected human cervical cancer HeLa cells or human osteosarcoma MG-63 cells, the efficiency of which could be markedly improved through the conjugation of oleate to the PAMAM [145], and folate-displaying graphene derivatives that target cancer cells were shown to be efficiently internalized through endocytosis and non-toxic towards human cervical cancer HeLa cells and human lung cancer A549 cells [146]. Complexes of carboxy-functionalized graphene, PAMAMs, epirubicin (an anticancer drug), amine-functionalized diethylene triamine pentaacetic acid loaded with $\mathrm{Gd}$ (a contrast agent), and either plasmid DNA (encoding GFP) or Let-7g targeting microRNA, were effective at the delivery of both the chemotherapeutic drug and therapeutic genetic material, and moreover simultaneous imaging, as demonstrated in vitro in human glioblastoma (U87) cells, and in vivo in the brains of mice, highlighting the potential of graphene-based theranostics [147].

\section{CONJUGATED POLYMER-BASED NON-VIRAL VECTORS FOR GENE DELIVERY}

The history of conjugated polymers is longer than for other classes of OEMs. The unintentional synthesis of polyaniline (Fig. 2) first reported by Letheby in 1862 [148], and Bolto and Weiss reported the first intentional syntheses of analogous polymers in a series of papers in 1963 and 1964 [149-154], it was however the more widely publicized work of Heeger, MacDiarmid and Shirakawa in the late 1970s [155-158] that led to an explosion of academic and industrial interest in the synthesis and applications of electroactive polymers (EAPs) [159, 160] and ultimately their award of the Nobel Prize in Chemistry in 2000. However, the development of conjugated polymers for gene delivery is still at a relatively nascent stage by comparison with the other classes of OEMs [161].

In common with fullerenes and graphenes [53], EAPs interact with DNA and RNA through non-covalent interactions, including van der Waals interactions, $\pi$-stacking interactions, hydrogen-bonding interactions and ionic interactions [162-166]. Their chemistry is well described in the literature, and similar to other OEMs used for gene therapy frequently involves functionalization with cationic species, for example, complexes of PEI-functionalized polythiophene (Fig. 6A) with siRNA (targeting luciferase) transfected human lung cancer A549-luc cells and successfully knocked down luciferase expression in vitro [167]. 
Complexes of cationic derivatives of poly(fluorenylene phenylene) displaying lipids (Fig. 6B) with plasmid DNA (encoding GFP) were capable of transfecting human lung cancer A549 cells [168], human cervical cancer HeLa cells and human breast cancer MCF7/ADR cells with greater efficiency in vitro than both Lipofectamine ${ }^{\circledR} 2000$ and PEI [169], and their high fluorescence facilitated real-time tracking of their location. Likewise, complexes of cationic oligofluorenes (Fig. 6C) with transrenal DNA (TR-T5) delivered their payload to human lung cancer A549 cells concomitant with visualization in vitro [170], and hyperbranched polyfluorene derivatives displaying cationic PEI transfected plasmid DNA (encoding luciferase) into monkey kidney fibroblast cell-like cells in vitro [171].

Complexes of cationic poly(phenylene ethynylene) derivatives (Fig. 6D) with siRNA (targeting specific genes in the cellulose biosynthesis pathway, NtCesA-1a and NtCesA1b) successfully transfected tobacco BY-2 protoplasts in vitro [172], or siRNA (against actin B) to human cervical cancer HeLa cells in vitro successfully down regulating the target gene expression by $94 \%$ [173]. Interestingly, complexes of cationic poly( $p$-phenylene vinylene) derivatives (Fig. 6E) with siRNA (targeting luciferase) successfully transfected human cervical cancer HeLa-Luc cells and diminished luciferase expression in vitro and this effect was enhanced photothemally upon exposure to white light [174].

Importantly, cationic derivatives of conjugated polymers can bind DNA/RNA and release it in response to electrochemical triggers, for example a cationic derivative of polycyclopentadithiophene (Fig. 6F) can release DNA using voltammetry scans of -0.3 to $+0.5 \mathrm{~V}$ versus a saturated calomel electrode [175] or polythiophene (Fig. 6G) can release DNA using voltammetry scans of -0.5 to $-2.4 \mathrm{~V}$ versus a saturated calomel electrode [176], suggesting the potential for electrochemically induced DNA/RNA delivery. We believe that biodegradable conjugated polymers [177, 178] such as those depicted in (Fig. 6, H, I and J) may have an important role to play in their translation from the bench to the clinic.

\section{CONCLUSION}

The delivery of DNA/RNA as a pharmaceutical means to treat various diseases (i.e., gene therapy) is now a wellestablished field of science. While a variety of vectors have been investigated (including viruses, nanoparticles, etc.), the use of organic electronic material-based vectors was the focus of this review; touching on their chemical structures (Fig. 7), surface modification, interactions with DNA/RNA, and their efficacy as gene delivery vectors both in vitro and in vivo. Their greater efficacy relative to current commercially available nonviral vectors and their beneficial theranostic properties make them incredibly attractive for further investigation, particularly in light of the evidence that they are biodegradable, and it is likely that the first clinical trials for such materials will be in the near future.

\section{CONFLICT OF INTEREST}

The authors confirm that there are no conflicts of interest regarding this review article.

\section{ACKNOWLEDGEMENTS}

KFAC gratefully acknowledges the NSERC-CREATE Training Program in Integrated Sensors Systems at McGill University for financial support. JGH gratefully acknowledges the Lancaster University Faculty of Science and Technology Early Career Internal Grant for financial support.

\section{REFERENCES}

[1] Sheridan C. Gene therapy finds its niche. Nat Biotech 2011; 29(2): 121128.

[2] Midoux P, Breuzard G, Gomez JP, Pichon C. Polymer-Based Gene Delivery: A Current Review on the Uptake and Intracellular Trafficking of Polyplexes. Curr Gene Therapy 2008; 8(5): 335-352.

[3] Pack DW, Hoffman AS, Pun S, Stayton PS. Design and development of polymers for gene delivery. Nat Rev Drug Disc 2005, 4(7): 581-593.

[4] Yin H, Kanasty RL, Eltoukhy AA, Vegas AJ, Dorkin JR, Anderson DG. Non-viral vectors for gene-based therapy. Nat Rev Genet 2014; 15(8):54155.

[5] Bryant LM, Christopher DM, Giles AR, et al. Lessons Learned from the Clinical Development and Market Authorization of Glybera. Human Gene Therapy Clin Dev 2013; 24(2): 55-64.

[6] Melchiorri D, Pani L, Gasparini P, et al. Regulatory evaluation of Glybera in Europe - two committees, one mission. Nat Rev Drug Disc 2013; 12(9): 719.

[7] Ylae-Herttuala S. Endgame: Glybera Finally Recommended for Approval as the First Gene Therapy Drug in the European Union. Mol Ther 2012; 20(10), 1831-1832.

[8] Petry H. Glybera (R) approval: a road map for advanced therapies in the orphan space. Human Gene Therapy 2013; 24(12): A5-A5.

[9] Takahashi S, Ito Y, Hatake K, Sugimoto Y. Gene therapy for breast cancer. --Review of clinical gene therapy trials for breast cancer and MDR1 gene therapy trial in Cancer Institute Hospital. Breast Cancer 2006; 13(1): 815 .

[10] Douglas MR. Gene therapy for Parkinson's disease: state-of-the-art treatments for neurodegenerative disease, Expert Review of Neurotherapeutics 2013; 13(6): 695-705.

[11] Forsayeth J, Bankiewicz KS, Aminoff MJ. Gene therapy for Parkinson's disease: where are we now and where are we going? Expert Review of Neurotherapeutics 2010; 10(12): 1839-1845.

[12] Nobre RJ, de Almeida LP. Gene Therapy for Parkinson's and Alzheimer's Diseases: from the Bench to Clinical Trials, Curr Pharm Des 2011; 17(31): 3434-3445.

[13] Onodera M, Kaneko S, Otsu M, et al. Gene Therapy Clinical Trials for Relapsed Leukemia with Infusions of the Suicide-Gene Transduced Donor Lymphocytes in Japan. Mol Ther 2006, 13, S426-S426.

[14] Berggren M, Richter-Dahlfors A. Organic Bioelectronics. Adv Mater 2007; 19(20): 3201-3213.

[15] Green RA, Lovell NH, Wallace GG, Poole-Warren LA. Conducting polymers for neural interfaces: Challenges in developing an effective longterm implant. Biomaterials 2008; 29(24-25): 3393-3399.

[16] Rivnay J, Owens RM, Malliaras GG. The Rise of Organic Bioelectronics. Chemistry of Materials 2014; 26(1): 679-685.

[17] Wilson AN, Guiseppi-Elie A. Bioresponsive Hydrogels. Adv Healthcare Mater 2013; 2(4): 520-532.

[18] Saito N, Haniu H, Usui Y, et al. Safe Clinical Use of Carbon Nanotubes as Innovative Biomaterials. Chem Rev 2014; 114(11): 60406079 .

[19] Bitounis D, Ali-Boucetta H, Hong BH, Min D, Kostarelos K. Prospects and Challenges of Graphene in Biomedical Applications. Adv Mater 2013; 25(16): 2258-2268.

[20] Hardy JG, Lee JY, Schmidt CE. Biomimetic conducting polymerbased tissue scaffolds. Curr Opin Biotechnol 2013; 24(5): 847-854.

[21] Muthu MS, Leong DT, Mei L, Feng S-S. Nanotheranostics Application and Further Development of Nanomedicine Strategies for Advanced Theranostics. Theranostics 2014; 4(6): 660-677.

[22] Prylutskyy Y, Bychko A, Sokolova V, et al. Interaction of C60 fullerene complexed to doxorubicin with model bilipid membranes and its uptake by HeLa cells. Mater Sci Eng C Mater Biol Appl 2016; 59: 398 403. 
[23] Skorkina MY, Sladkova EA, Shamray EA, et al., C60 fullerene affects elastic properties and osmoregulation reactions of human lymphocytes. Eur Biophys J 2015; 44: 493-8.

[24] Shpakova NM, Nipot OS, Ishchenko IO, et al., Effect of C60 fullerene on viscoelastic properties of human erythrocytes membrane. Fiziol Zh 2014; 60: $82-8$.

[25] Sumner SCJ, Snyder RW, Wingard C, et al., Distribution and biomarkers of carbon-14-labeled fullerene C-60 ( C-14(U) C-60) in female rats and mice for up to 30 days after intravenous exposure. J Appl Toxicol 2015; 35: 1452-1464.

[26] Nakamura E, Isobe H, Tomita N, Sawamura M, Jinno S, Okayama H. Functionalized fullerene as an artificial vector for transfection. Angew Chem Int Ed 2000; 39(23): 4254-4257.

[27] Isobe H, Nakanishi W, Tomita N, Jinno S, Okayama H, Nakamura E. Nonviral gene delivery by tetraamino fullerene. Mol Pharm 2006; 3(2): 124-134.

[28] Lucafo M, Pelillo C, Carini M, Da Ros T, Prato M, Sava G. A Cationic 60 Fullerene Derivative Reduces Invasion and Migration of HT-29 CRC Cells in Vitro at Dose Free of Significant Effects on Cell Survival. NanoMicro Letters, 2014; 6(2): 163-168.

[29] Li Y, Gan L. Selective Addition of Secondary Amines to C-60: Formation of Penta- and Hexaamino[60]fullerenes. J Org Chem 2014; 7(18): 8912-8916.

[30] Sitharaman B, Zakharian TY, Saraf A, et al. Water-soluble fullerene (C-60) derivatives as nonviral gene-delivery vectors, Mol Pharm 2008; 5(4): 567-578.

[31] Klumpp C, Lacerda L, Chaloin O, et al. Multifunctionalised cationic fullerene adducts for gene transfer: design, synthesis and DNA complexation. Chem Commun 2007; 36: 3762-3764.

[32] Nitta H, Minami K, Harano K, Nakamura E. DNA Binding of Pentaamino[60]fullerene Synthesized Using Click Chemistry. Chem Lett 2015; 44(3): 378-380.

[33] Hung CH, Chang WW, Liu SC, et al. Self-aggregation of amphiphilic [60]fullerenyl focal point functionalized PAMAM dendrons into pseudodendrimers: DNA binding involving dendriplex formation. J Biomed Mater Res A 2015; 103(5): 1595-604.

[34] Uritu CM, Varganici CD, Ursu L, et al. Hybrid fullerene conjugates as vectors for DNA cell-delivery. J Mater Chem B 2015; 3(12): 2433-2446.

[35] Isobe H, Nakanishi W, Tomita N, Jinno S, Okayama H, Nakamura E. Gene delivery by aminofullerenes: Structural requirements for efficient transfection. Chem Asian J, 2006; 1(1-2): 167-175.

[36] Maeda-Mamiya $\mathrm{R}$, Noiri $\mathrm{E}$, Isobe $\mathrm{H}$, et al. In vivo gene delivery by cationic tetraamino fullerene. Proc Nat Acad Sci USA 2010; 107(12): 53395344.

[37] Minami K, Okamoto K, Doi K, Harano K, Noiri E, Nakamura E. siRNA delivery targeting to the lung via agglutination-induced accumulation and clearance of cationic tetraamino fullerene. Sci Rep 2014; 4: 4916.

[38] Bardi G, Nunes A, Gherardini L, et al. Functionalized Carbon Nanotubes in the Brain: Cellular Internalization and Neuroinflammatory Responses. Plos One 2013; 8(11): e80964.

[39] Huang X, Zhang F, Sun X, et al. The genotype-dependent influence of functionalized multiwalled carbon nanotubes on fetal development, Biomaterials 2014; 35(2): 856-865.

[40] Thongkumkoon P, Sangwijit K, Chaiwong C, Thongtem S, Singjai P, Yu LD. Direct nanomaterial-DNA contact effects on DNA and mutation induction. Toxicol Lett 2014; 226(1): 90-97.

[41] Lamberti M, Pedata P, Sannolo N, Porto S, De Rosa A, Caraglia M. Carbon nanotubes: Properties, biomedical applications, advantages and risks in patients and occupationally-exposed workers. Int J Immunopathol Pharmacol 2015; 28(1): 4-13.

[42] Chatterjee N, Yang J, Kim H, Jo E, Kim P, Choi K, Choi J. Potential Toxicity of Differential Functionalized Multiwalled Carbon Nanotubes (MWCNT) in Human Cell Line (BEAS2B) and Caenorhabditis elegans. J Toxicol Env Health-Part A-Current Issues 2014; 77(22-24): 1399-1408.

[43] Battigelli A, Menard-Moyon C, Da Ros T, Prato M, Bianco A. Endowing carbon nanotubes with biological and biomedical properties by chemical modifications, Adv Drug Del Rev 2013; 65(15): 1899-1920.

[44] Bianco A, Kostarelos K, Partidos CD, Prato M. Biomedical applications of functionalised carbon nanotubes. Chem Commun 2005; 5 : 571-577.

[45] Bhirde AA, Patel V, Gavard J, et al. Targeted Killing of Cancer Cells in Vivo and in Vitro with EGF-Directed Carbon Nanotube-Based Drug Delivery. ACS Nano 2009; 3(2): 307-316.
[46] Gul-Uludag H, Lu W, Xu P, Xing J, Chen J. Efficient and rapid uptake of magnetic carbon nanotubes into human monocytic cells: implications for cell-based cancer gene therapy. Biotechnology Letters 2012; 34(5): 989993.

[47] Al-Jamal KT, Gherardini L, Bardi G, et al. Functional motor recovery from brain ischemic insult by carbon nanotube-mediated siRNA silencing. Proc Nat Acad Sci USA 2011; 108(27): 10952-10957.

[48] Bianco A, Kostarelos K, Prato M. Making carbon nanotubes biocompatible and biodegradable. Chem Commun 2011; 47(37): 1018210188.

[49] Bates K, Kostarelos K. Carbon nanotubes as vectors for gene therapy: Past achievements, present challenges and future goals, Adv Drug Del Rev, 2013; 65(15): 2023-2033.

[50] Caoduro C, Hervouet E, Girard-Thernier C, et al. Carbon nanotubes as gene carriers: Focus on internalization pathways related to functionalization and properties. Acta Biomater 2016; DOI:10.1016/j.actbio.2016.11.013.

[51] Sharma P, Mehra NK, Jain K, Jain NK. Biomedical Applications of Carbon Nanotubes: A Critical Review. Curr Drug Deliv 2016; 13(6): 796817.

[52] Alshehri R, Ilyas AM, Hasan A, Arnaout A, Ahmed F, Memic A. Carbon Nanotubes in Biomedical Applications: Factors, Mechanisms, and Remedies of Toxicity. J Med Chem 2016; 59(18): 8149-67.

[53] Nandy B, Santosh M, Maiti PK. Interaction of nucleic acids with carbon nanotubes and dendrimers. J Biosci 2012; 37(3): 457-474.

[54] Alidori S, Asqiriba K, Londero P, et al. Deploying RNA and DNA with Functionalized Carbon Nanotubes, Journal of Physical Chemistry C, 2013; 117(11): 5982-5992.

[55] Sanz V, Borowiak E, Lukanov P, et al. Optimising DNA binding to carbon nanotubes by non-covalent methods. Carbon 2011; 49(5): 17751781.

[56] Sanz V, Coley HM, Silva SRP, McFadden J. Modeling the binding of peptides on carbon nanotubes and their use as protein and DNA carriers. J Nanoparticle Res 2012; 14(2): 695.

[57] Sanz V, Tilmaciu C, Soula B, et al. Chloroquine-enhanced gene delivery mediated by carbon nanotubes. Carbon 2011; 49(15): 5348-5358.

[58] Shen J-W, Tang T, Wei X-H, et al. On the loading mechanism of ssDNA into carbon nanotubes. RSC Adv 2015; 5: 56896-56903.

[59] Ghosh S, Patel N, Chakrabarti R. Probing the Salt Concentration Dependent Nucelobase Distribution in a Single-Stranded DNA-SingleWalled Carbon Nanotube Hybrid with Molecular Dynamics. J Phys Chem B 2016; 120(3): 455-66.

[60] Ghosh S, Patel N, Chakrabarti R. Correction to Probing the Salt Concentration Dependent Nucleobase Distribution in a Single-Stranded DNA-Single-Walled Carbon Nanotube Hybrid with Molecular Dynamics. J Phys Chem B 2016; 120(10): 2868.

[61] Munk M, Ladeira LO, Carvalho BC, et al. Efficient delivery of DNA into bovine preimplantation embryos by multiwall carbon nanotubes. Sci Rep 2016; 6: 33588 .

[62] Neves V, Heister E, Costa S, et al. Design of double-walled carbon nanotubes for biomedical applications. Nanotechnol 2012; 23(36): 365102.

[63] Neves V, Heister E, Costa S, et al. Uptake and Release of DoubleWalled Carbon Nanotubes by Mammalian Cells. Adv Funct Mater 2010; 20(19): 3272-3279.

[64] Jeynes JCG, Mendoza E, Chow DCS, Watts PCR, McFadden J, Silva SRP. Generation of chemically unmodified pure single-walled carbon nanotubes by solubilizing with RNA and treatment with ribonuclease A, Adv Mater 2006; 18(12): 1598-1602.

[65] Monajjemi M, Karachi N, Mollaamin F. The Investigation of Sequence-dependent Interaction of Messenger RNA Binding to Carbon Nanotube. Fullerenes Nanotubes and Carbon Nanostructures 2014; 22(7): 643-662.

[66] Huzil JT, Saliaj E, Ivanova MV, et al. Selective nuclear localization of siRNA by metallic versus semiconducting single wall carbon nanotubes in keratinocytes. Future Sci OA 2015; 1(3): FSO17.

[67] Tonelli FMP, Lacerda SMSN, Silva MA, et al. Gene delivery to Nile tilapia spermatogonial stem cells using carboxi-functionalized multiwall carbon nanotubes. RSC Adv 2014; 4(72): 37985-37987.

[68] Audouy S, Hoekstra D. Cationic lipid-mediated transfection in vitro and in vivo. Molecular Membrane Biology 2001; 18(2): 129-143.

[69] Gascon AR, Luis Pedraz J. Cationic lipids as gene transfer agents: a patent review. Exp Opin Ther Patents 2008; 18(5): 515-524.

[70] Misra SK, Moitra P, Chhikara BS, Kondaiah P, Bhattacharya S. Loading of single-walled carbon nanotubes in cationic cholesterol suspensions significantly improves gene transfection efficiency in serum, $\mathrm{J}$ Mater Chem 2012; 22(16): 7985-7998. 
[71] Anderson T, Hu R, Yang C, Yoon HS, Yong K. Pancreatic cancer gene therapy using an siRNA-functionalized single walled carbon nanotubes (SWNTs) nanoplex. Biomater Sci 2014; 2(9): 1244-1253.

[72] Pereira S, Lee J, Rubio N, et al. Cationic Liposome- Multi-Walled Carbon Nanotubes Hybrids for Dual siPLK1 and Doxorubicin Delivery In Vitro. Pharm Res 2015; 32(10): 3293-308.

[73] Guo C, Al-Jamal WT, Toma FM, et al. Design of Cationic Multiwalled Carbon Nanotubes as Efficient siRNA Vectors for Lung Cancer Xenograft Eradication. Bioconjug Chem 2015; 26(7): 1370-9.

[74] Siu KS, Zheng X, Liu Y, et al. Single-Walled Carbon Nanotubes Noncovalently Functionalized with Lipid Modified Polyethylenimine for siRNA Delivery in Vitro and in Vivo. Bioconj Chem 2014; 25(10): 17441751.

[75] Kostiainen MA, Hardy JG, Smith DK. High-affinity multivalent DNA binding by using low-molecular-weight dendrons. Angew Chem Int Ed 2005; 44(17): 2556-2559.

[76] Hardy JG, Kostiainen MA, Smith DK, Gabrielson NP, Pack DW. Dendrons with spermine surface groups as potential building blocks for nonviral vectors in gene therapy. Bioconjugate chemistry 2006; 17(1): 172178.

[77] Kostiainen MA, Szilvay GR, Lehtinen J, et al. Precisely defined protein-polymer conjugates: construction of synthetic DNA binding domains on proteins by using multivalent dendrons. ACS Nano 2007; 1(2): 103-113.

[78] Welsh DJ, Jones SP, Smith DK. On-Off Multivalent Recognition: Degradable Dendrons for Temporary High-Affinity DNA Binding. Angew Chem Int Ed 2009; 48(22): 4047-4051

[79] Pavan GM, Danani A, Pricl S, Smith DK. Modeling the Multivalent Recognition between Dendritic Molecules and DNA: Understanding How Ligand Sacrifice and Screening Can Enhance Binding. J Am Chem Soc 2009; 131(28): 9686-9694.

[80] Singh P, Samori C, Toma,FM, et al. Polyamine functionalized carbon nanotubes: synthesis, characterization, cytotoxicity and siRNA binding. Mater Chem 2011; 21(13): 4850-4860.

[81] Xia W, Lin C. Bioreducible polymer-delivered siRNA targeting human telomerase reverse transcriptase for human cancer gene therapy. Ther Deliv 2012; 3(4): 439-42.

[82] Kim P, Kim T, Yockman JW, Kim SW, Yun C. The effect of surface modification of adenovirus with an arginine-grafted bioreducible polymer on transduction efficiency and immunogenicity in cancer gene therapy. Biomaterials 2010; 31(7): 1865-1874.

[83] Hardy JG, Love CS, Gabrielson NP, Pack DW, Smith DK. Synergistic effects on gene delivery - co-formulation of small disulfide-linked dendritic polycations with Lipofectamine 2000 (TM). Org Biomol Chem 2009; 7(4): 789-793.

[84] Chen H, Ma X, Li Z, Shi Q, Zheng W, Liu Y, Wang P. Functionalization of single-walled carbon nanotubes enables efficient intracellular delivery of siRNA targeting MDM2 to inhibit breast cancer cells growth. Biomed Pharmacother 2012; 66(5): 334-338.

[85] Karmakar A, Bratton SM, Dervishi E, et al. Ethylenediamine functionalized-single-walled nanotube (f-SWNT)-assisted in vitro delivery of the oncogene suppressor p53 gene to breast cancer MCF-7 cells. Int J Nanomed 2011; 6: 1045-1055.

[86] Zhu B, Liu GL, Gong YX, Ling F, Wang GX. Protective immunity of grass carp immunized with DNA vaccine encoding the vp7 gene of grass carp reovirus using carbon nanotubes as a carrier molecule. Fish Shellfish Immunol 2015; 42(2): 325-34.

[87] Wang Y, Liu GL, Li DL, Ling F, Zhu B, Wang GX. The protective immunity against grass carp reovirus in grass carp induced by a DNA vaccination using single-walled carbon nanotubes as delivery vehicles. Fish Shellfish Immunol 2015; 47(2): 732-42.

[88] Zhou Y, Jiang N, Ma J, et al. Protective immunity in gibel carp, Carassius gibelio of the truncated proteins of cyprinid herpesvirus 2 expressed in Pichia pastoris. Fish Shellfish Immunol 2015; 47(2): 1024-31.

[89] Liu L, Gong YX, Liu GL, Zhu B, Wang GX. Protective immunity of grass carp immunized with DNA vaccine against Aeromonas hydrophila by using carbon nanotubes as a carrier molecule. Fish Shellfish Immunol 2016; 55: 516-22.

[90] Andreoli E, Suzuki R, Orbaek AW, et al. Preparation and evaluation of polyethyleneimine-single walled carbon nanotube conjugates as vectors for pancreatic cancer treatment. J Mater Chem B 2014; 2(29): 4740-4747.

[91] Moradian H, Fasehee H, Keshvari H, Faghihi S. Poly(ethyleneimine) functionalized carbon nanotubes as efficient nano-vector for transfecting mesenchymal stem cells. Coll Surf B-Biointerfaces 2014; 122: 115-125.
[92] Oliveira JM, Salgado AJ, Sousa N, Mano JF, Reis RL. Dendrimers and derivatives as a potential therapeutic tool in regenerative medicine strategies-A review. Progr Polym Sci 2010; 35(9): 1163-1194.

[93] Wu J, Huang W, He Z. Dendrimers as Carriers for siRNA Delivery and Gene Silencing: A Review. Sci World J 2013: 630654.

[94] Masotti A, Miller MR, Celluzzi A, et al. Regulation of angiogenesis through the efficient delivery of microRNAs into endothelial cells using polyamine-coated carbon nanotubes. Nanomedicine 2016; 12(6):1511-22.

[95] Varkouhi AK, Foillard S, Lammers T, et al. SiRNA delivery with functionalized carbon nanotubes. Int J Pharm 2011; 416(2): 419-425.

[96] Behnam B, Shier WT, Nia AH, Abnous K, Ramezani M. Non-covalent functionalization of single-walled carbon nanotubes with modified polyethyleneimines for efficient gene delivery. Int J Pharm 2013; 454(1): 204-215.

[97] Nia AH, Amini A, Taghavi S, Eshghi H, Abnous K, Ramezani M. A facile Friedel-Crafts acylation for the synthesis of polyethylenimine-grafted multi-walled carbon nanotubes as efficient gene delivery vectors. Int $\mathbf{J}$ Pharm 2016; 502(1-2): 125-37.

[98] Liu M, Chen B, Xue Y, et al. Polyamidoamine-Grafted Multiwalled Carbon Nanotubes for Gene Delivery: Synthesis, Transfection and Intracellular Trafficking. Bioconj Chem 2011; 22(11): 2237-2243.

[99] Qin W, Yang K, Tang H, et al. Improved GFP gene transfection mediated by polyamidoamine dendrimer-functionalized multi-walled carbon nanotubes with high biocompatibility. Coll Surf B-Biointerfaces 2011; 84(1): 206-213.

[100] Yang K, Qin W, Tang H, et al. Polyamidoamine dendrimerfunctionalized carbon nanotubes-mediated GFP gene transfection for HeLa cells: Effects of different types of carbon nanotubes. J Biomed Mater Res Part A 2011; 99A(2): 231-239.

[101] Antonia Herrero M, Toma FM, Al-Jamal KT, et al. Synthesis and Characterization of a Carbon Nanotube-Dendron Series for Efficient siRNA Delivery. J Am Chem Soc 2009; 131(28): 9843-9848.

[102] Battigelli A, Wang JT, Russier J, et al. Ammonium and Guanidinium Dendron-Carbon Nanotubes by Amidation and Click Chemistry and their Use for siRNA Delivery. Small 2013; 9(21): 3610-3619.

[103] Pan B, Cui D, Xu P, et al. Synthesis and characterization of polyamidoamine dendrimer-coated multi-walled carbon nanotubes and their application in gene delivery systems. Nanotechnol 2009; 20(12): 125101.

[104] Guerra J, Antonia Herrero M, Carrion B, et al. Carbon nanohorns functionalized with polyamidoamine dendrimers as efficient biocarrier materials for gene therapy. Carbon 2012; 50(8): 2832-2844.

[105] Marchetti C, Palaia I, Giorgini M, et al. Targeted drug delivery via folate receptors in recurrent ovarian cancer: a review. Oncotargets and Therapy 2014; 7: 1223-1236.

[106] Liu X, Zhang Y, Ma D. et al. Biocompatible multi-walled carbon nanotube-chitosan-folic acid nanoparticle hybrids as GFP gene delivery materials, Coll Surf B-Biointerfaces 2013; 111: 224-231.

[107] Taghavi S, HashemNia A, Mosaffa F, Askarian S, Abnous K, Ramezani M. Preparation and evaluation of polyethyleniminefunctionalized carbon nanotubes tagged with 5TR1 aptamer for targeted delivery of Bcl-xL shRNA into breast cancer cells. Coll Surf B Biointerfaces 2016; 140: 28-39.

[108] Taghavi S, Nia AH, Abnous K, Ramezani M. Polyethyleniminefunctionalized carbon nanotubes tagged with AS1411 aptamer for combination gene and drug delivery into human gastric cancer cells. Int J Pharm 2017; 516(1-2): 301-312.

[109] Ohta T, Hashida Y, Higuchi Y, Yamashita F, Hashida M. In Vitro Cellular Gene Delivery Employing a Novel Composite Material of SingleWalled Carbon Nanotubes Associated With Designed Peptides With Pegylation. J Pharm Sci 2016; DOI: 10.1016/j.xphs.2016.10.025.

[110] Ohta T, Hashida Y, Yamashita F, Hashida M. Development of Novel Drug and Gene Delivery Carriers Composed of Single-Walled Carbon Nanotubes and Designed Peptides With PEGylation. J Pharm Sci 2016; 105(9): 2815-24.

[111] Wang L, Shi J, Zhang H, et al. Synergistic anticancer effect of RNA and photothermal therapy mediated by functionalized single-walled carbon nanotubes. Biomaterials 2013; 34(1): 262-274.

[112] Jain S, Thanki K, Pandia NK, Kushwaha V. Estradiol functionalized multi-walled carbon nanotubes as renovated strategy for efficient gene delivery. RSC Adv 2016; 6: 10792-10801.

[113] Kong F, Liu F, Li W, et al. Smart Carbon Nanotubes with LaserControlled Behavior in Gene Delivery and Therapy through a NonDigestive Trafficking Pathway. Small 2016; 12(48): 6753-6766. 
[114] Wang JT, Cabana L, Bourgognon M, et al. Magnetically Decorated Multiwalled Carbon Nanotubes as Dual MRI and SPECT Contrast Agents. Adv Funct Mater 2014; 24(13): 1880-1894.

[115] Singh RK, Patel KD, Kim J, et al. Multifunctional Hybrid Nanocarrier: Magnetic CNTs Ensheathed with Mesoporous Silica for Drug Delivery and Imaging System. ACS Appl Mater Int 2014; 6(4): 2201-2208. [116] He L, Huang Y, Zhu H, et al. Cancer-Targeted Monodisperse Mesoporous Silica Nanoparticles as Carrier of Ruthenium Polypyridyl Complexes to Enhance Theranostic Effects. Adv Funct Mater 2014; 24(19): 2754-2763.

[117] Raffa V, Gherardini L, Vittorio O, et al. Carbon nanotube-mediated wireless cell permeabilization: drug and gene uptake. Nanomedicine 2011; 6(10): 1709-1718.

[118] Rojas-Chapana JA, Correa-Duarte MA, Ren ZF, Kempa K, Giersig M. Enhanced introduction of gold nanoparticles into vital Acidothiobacillus ferrooxidans by carbon nanotube-based microwave electroporation. Nano Lett 2004; 4(5): 985-988.

[119] Feng L, Zhang S, Liu Z. Graphene based gene transfection. Nanoscale 2011; 3(3): 1252-1257.

[120] Girish CM, Sasidharan A, Gowd GS, Nair S, Koyakutty M. Confocal Raman Imaging Study Showing Macrophage Mediated Biodegradation of Graphene In Vivo. Adv Healthcare Mater 2013, 2(11), 1489-1500.

[121] Vincent M, de Lázaro I, Kostarelos K. Graphene materials as 2D nonviral gene transfer vector platforms. Gene Ther 2016; DOI: 10.1038/gt.2016.79.

[122] Byun J. Emerging frontiers of graphene in biomedicine. J Microbiol Biotechnol 2015; 25(2): 145-51.

[123] McCallion C, Burthem J, Rees-Unwin K, Golovanov A, Pluen A. Graphene in therapeutics delivery: Problems, solutions and future opportunities. Eur J Pharm Biopharm 2016; 104: 235-50.

[124] Wu SY, An SS, Hulme J. Current applications of graphene oxide in nanomedicine. Int J Nanomedicine 2015; 10: 9-24.

[125] Yang K, Feng L, Liu Z. Stimuli responsive drug delivery systems based on nano-graphene for cancer therapy. Adv Drug Deliv Rev 2016; 105 : 228-241.

[126] Zhang B, Wang Y, Zhai G. Biomedical applications of the graphenebased materials. Mater Sci Eng C 2016; 61: 953-964.

[127] Chen J, Chen L, Wang Y, Chen S. Molecular dynamics simulations of the adsorption of DNA segments onto graphene oxide. J Phys D-Appl Phys 2014; 47(50): 505401.

[128] Chowdhury SM, Zafar S, Tellez V, Sitharaman B. Graphene Nanoribbon-Based Platform for Highly Efficacious Nuclear Gene Delivery. ACS Biomater Sci Eng 2016; 2(5): 798-808.

[129] Imani R, Emami SH, Faghihi S. Synthesis and characterization of an octaarginine functionalized graphene oxide nano-carrier for gene delivery applications. Phys Chem Chem Phys 2015; 17(9): 6328-39.

[130] Imani R, Shao W, Taherkhani S, Emami SH, Prakash S, Faghihi S. Dual-functionalized graphene oxide for enhanced siRNA delivery to breast cancer cells. Coll Surf B Biointerfaces 2016; 147: 315-25.

[131] Rezaei A, Akhavan O, Hashemi E, Shamsara M. Toward Chemical Perfection of Graphene-Based Gene Carrier via Ugi Multicomponent Assembly Process. Biomacromolecules 2016; 17(9): 2963-71.

[132] Dong H, Dai W, Ju H, et al. Multifunctional Poly(L-lactide)Polyethylene Glycol-Grafted Graphene Quantum Dots for Intracellular MicroRNA Imaging and Combined Specific-Gene-Targeting Agents Delivery for Improved Therapeutics. ACS Appl Mater Interfaces 2015; 7(20): 11015-23.

[133] Yang X, Zhao N, Xu F. Biocleavable graphene oxide basednanohybrids synthesized via ATRP for gene/drug delivery. Nanoscale 2014; 6(11): 6141-6150.

[134] Kim H, Kim J, Lee M, Choi HC, Kim WJ. Stimuli-Regulated Enzymatically Degradable Smart Graphene-Oxide-Polymer Nanocarrier Facilitating Photothermal Gene Delivery. Adv Healthc Mater 2016; 5(15): 1918-30.

[135] Teimouri M, Nia AH, Abnous K, Eshghi H, Ramezani M. Graphene oxide-cationic polymer conjugates: Synthesis and application as gene delivery vectors. Plasmid 2016; 84-85: 51-60.

[136] Kim H, Kim WJ. Photothermally Controlled Gene Delivery by Reduced Graphene Oxide-Polyethylenimine Nanocomposite. Small 2014; 10(1), 117-126.

[137] Feng L, Yang X, Shi X, et al. Polyethylene Glycol and Polyethylenimine Dual-Functionalized Nano-Graphene Oxide for Photothermally Enhanced Gene Delivery. Small 2013; 9(11): 1989-1997.
[138] Huang YP, Hung CM, Hsu YC, et al. Suppression of Breast Cancer Cell Migration by Small Interfering RNA Delivered by PolyethylenimineFunctionalized Graphene Oxide. Nanoscale Res Lett 2016; 11(1): 247.

[139] Yin D, Li Y, Guo B, et al. Plasmid-Based Stat3 siRNA Delivered by Functional Graphene Oxide Suppresses Mouse Malignant Melanoma Cell Growth. Oncol Res 2016; 23(5): 229-36.

[140] He Y, Zhang L, Chen Z, et al. Enhanced chemotherapy efficacy by co-delivery of shABCG2 and doxorubicin with a $\mathrm{pH}$-responsive chargereversible layered graphene oxide nanocomplex. J Mater Chem B 2015; 3: 6462-6472.

[141] Choi HY, Lee TJ, Yang GM, et al. Efficient mRNA delivery with graphene oxide-polyethylenimine for generation of footprint-free human induced pluripotent stem cells. J Control Release 2016; 235: 222-35.

[142] Paul A, Hasan A, Al Kindi H, et al. Injectable Graphene Oxide/Hydrogel-Based Angiogenic Gene Delivery System for Vasculogenesis and Cardiac Repair. ACS Nano 2014; 8(8): 8050-8062. [143] Wang F, Zhang B, Zhou L, Shi Y, Li Z, Xia Y, Tian J. Imaging Dendrimer-Grafted Graphene Oxide Mediated Anti-miR-21 Delivery With an Activatable Luciferase Reporter. ACS Appl Mater Interfaces 2016; 8(14): 9014-21.

[144] Sarkar K, Madras G, Chatterjee K. Dendron conjugation to graphene oxide using click chemistry for efficient gene delivery. RSC Adv 2015; 5 : 50196-50211.

[145] Liu X, Ma D, Tang H, et al. Polyamidoamine Dendrimer and Oleic Acid-Functionalized Graphene as Biocompatible and Efficient Gene Delivery Vectors, ACS Appl Mater Interfaces 2014; 6(11), 8173-8183.

[146] Hu H, Tang C, Yin C. Folate conjugated trimethyl chitosan/graphene oxide nanocomplexes as potential carriers for drug and gene delivery. Mater Lett 2014; 125: 82-85.

[147] Yang H, Huang C, Lin C, et al. Gadolinium-functionalized nanographene oxide for combined drug and microRNA delivery and magnetic resonance imaging. Biomaterials 2014; 35(24): 6534-6542.

[148] Letheby H. XXIX. - On the production of a blue substance by the electrolysis of sulphate of aniline. J Chem Soc 1862; 15: 161-163.

[149] Bolto BA, Weiss DE. Electronic conduction in polymers: II. The electrochemical reduction of polypyrrole at controlled potential. Aust J Chem 1963; 63(16): 1076-1090.

[150] Bolto BA, McNeill R, Weiss DE. Electronic conduction in polymers: III. Electronic properties of polypyrrole. Aust J Chem 1963; 16(6): 10901103.

[151] Bolto BA, Weiss DE, Willis D. Electronic conduction in polymers. V. Aromatic semiconducting polymers. Aust J Chem 1965; 18(4): 487-491.

[152] McNeill R, Siudak R, Wardlaw JH, Weiss DE. Electronic conduction in polymers. I. The Chemical Structure of Polypyrrole. Aust J Chem 1963; 16: $1056-1075$.

[153] McNeill R, Weiss DE, Willis D. Electronic conduction in polymers. 4. Polymers from imidazole and pyridine. Aust J Chem 1965; 18(4): 477486.

[154] Macpherson AS, Siudak RV, Weiss DE, Willis D. Electronic conduction in polymers. 6 . Chemical consequences of space charge effects in conducting polymers. Aust J Chem 1965; 18(4): 493-505.

[155] Chiang CK, Druy MA, Gau SC, et al. Synthesis of Highly Conducting Films of Derivatives of Polyacetylene, (Ch)x. J Amer Chem Soc 1978; 100(3): 1013-1015.

[156] Chiang CK, Fincher CR, Park YW, et al. Electrical-Conductivity in Doped Polyacetylene. Phys Rev Lett 1977; 39(17), 1098-1101.

[157] Macdiarmid AG, Akhtar M, Chiang CK, et al. Electrically Conducting Covalent Polymers - Halogen Derivatives of $(\mathrm{Sn}) \mathrm{x}$ and $(\mathrm{Ch}) \mathrm{x}$. J Electrochem Soc 1977; 124(8): C304-C304.

[158] Shirakawa H, Louis EJ, Macdiarmid AG, Chiang CK, Heeger AJ. Synthesis of Electrically Conducting Organic Polymers - Halogen Derivatives of Polyacetylene, (Ch)x. J Chem Soc Chem Commun 1977; 16: 578-580.

[159] Svirskis D, Travas-Sejdic J, Rodgers A, Garg S. Electrochemically controlled drug delivery based on intrinsically conducting polymers. J Control Rel 2010; 146(1): 6-15.

[160] Pillay V, Tsai TS, Choonara YE, et al. A review of integrating electroactive polymers as responsive systems for specialized drug delivery applications. J Biomed Mater Res A 2014; 102(6): 2039-54.

[161] Yang G, Lv F, Wang B, Liu L, Yang Q, Wang S. Multifunctional Non-Viral Delivery Systems Based on Conjugated Polymers. Macromol Biosci 2012; 12(12): 1600-1614.

[162] Zanuy D, Aleman C. DNA-conducting polymer complexes: A computational study of the hydrogen bond between building blocks. J Phys Chem B 2008; 112(10): 3222-3230. 
[163] Saoudi B, Jammul N, Abel ML, Chehimi MM, Dodin G. DNA adsorption onto conducting polypyrrole. Synthetic Metals 1997; 87(2): 97103.

[164] Dutta P, Mandal SK. Charge transport in chemically synthesized, DNA-doped polypyrrole. J Phys D-Appl Phys 2004; 37(20): 2908-2913.

[165] Tang H, Duan X, Feng X, et al. Fluorescent DNApoly(phenylenevinylene) hybrid hydrogels for monitoring drug release. Chem Commun 2009; 6: 641-643.

[166] Yu M, Liu L, Wang, S. Water-Soluble Dendritic-Conjugated Polyfluorenes: Synthesis, Characterization, and Interactions with DNA. J Polym Sci Part A-Polym Chem 2008; 46(22): 7462-7472.

[167] He P, Hagiwara K, Chong H, Yu HH, Ito Y. Low-Molecular-Weight Polyethyleneimine Grafted Polythiophene for Efficient siRNA Delivery. Biomed Res Int 2015; 406389.

[168] Feng X, Tang Y, Duan X, Liu L, Wang S. Lipid-modified conjugated polymer nanoparticles for cell imaging and transfection. J Mater Chem 2010; 20(7): 1312-1316.

[169] Feng X, Lv F, Liu L, Yang Q, Wang S, Bazan GC. A Highly Emissive Conjugated Polyelectrolyte Vector for Gene Delivery and Transfection. Adv Mater 2012; 24(40): 5428-5432.

[170] Wang X, He F, Li L, Wang H, Yan R, Li L. Conjugated OligomerBased Fluorescent Nanoparticles as Functional Nanocarriers for Nucleic Acids Delivery. ACS Appl Mater Interfaces 2013; 5(12): 5700-5708.

[171] Wang G, Yin H, Ng JCY, et al. Polyethyleneimine-grafted hyperbranched conjugated polyelectrolytes: synthesis and imaging of gene delivery. Polym Chem 2013; 4(20): 5297-5304.

[172] Silva AT, Nguyen A, Ye C, Verchot J, Moon JH. Conjugated polymer nanoparticles for effective siRNA delivery to tobacco BY-2 protoplasts. BMC Plant Biology 2010; 10: 291.

\section{FIGURE LEGENDS}

[173] Moon JH, Mendez E, Kim Y, Kaur A. Conjugated polymer nanoparticles for small interfering RNA delivery. Chem Commun 2011; 47(29): 8370-8372.

[174] Li S, Yuan H, Chen H, et al. Cationic Poly(p-phenylene vinylene) Materials as a Multifunctional Platform for Light-Enhanced siRNA Delivery. Chem Asian J 2016; 11(19): 2686-2689.

[175] Gautier C, Cougnon C, Pilard J, Casse N, Chenais B. A poly(cyclopentadithiophene) matrix suitable for electrochemically controlled DNA delivery. Anal Chem 2007; 79(20): 7920-7923.

[176] Gautier C, Cougnon C, Pilard J, Casse N, Chenais B, Laulier M. Detection and modelling of DNA hybridization by EIS measurements Mention of a polythiophene matrix suitable for electrochemically controlled gene delivery. Biosens Bioelectron 2007; 22(9-10), 2025-2031.

[177] Hardy JG, Mouser DJ, Arroyo-Curras N, et al. Biodegradable electroactive polymers for electrochemically-triggered drug delivery, J Mater Chem B 2014; 2(39), 6809-6822.

[178] Hardy JG, Amend MN, Geissler S, Lynch VM, Schmidt CE. Peptidedirected assembly of functional supramolecular polymers for biomedical applications: electroactive molecular tongue-twisters (oligoalanineoligoaniline-oligoalanine) for electrochemically enhanced drug delivery. J Mater Chem B 2015; 3: 5005-5009. 

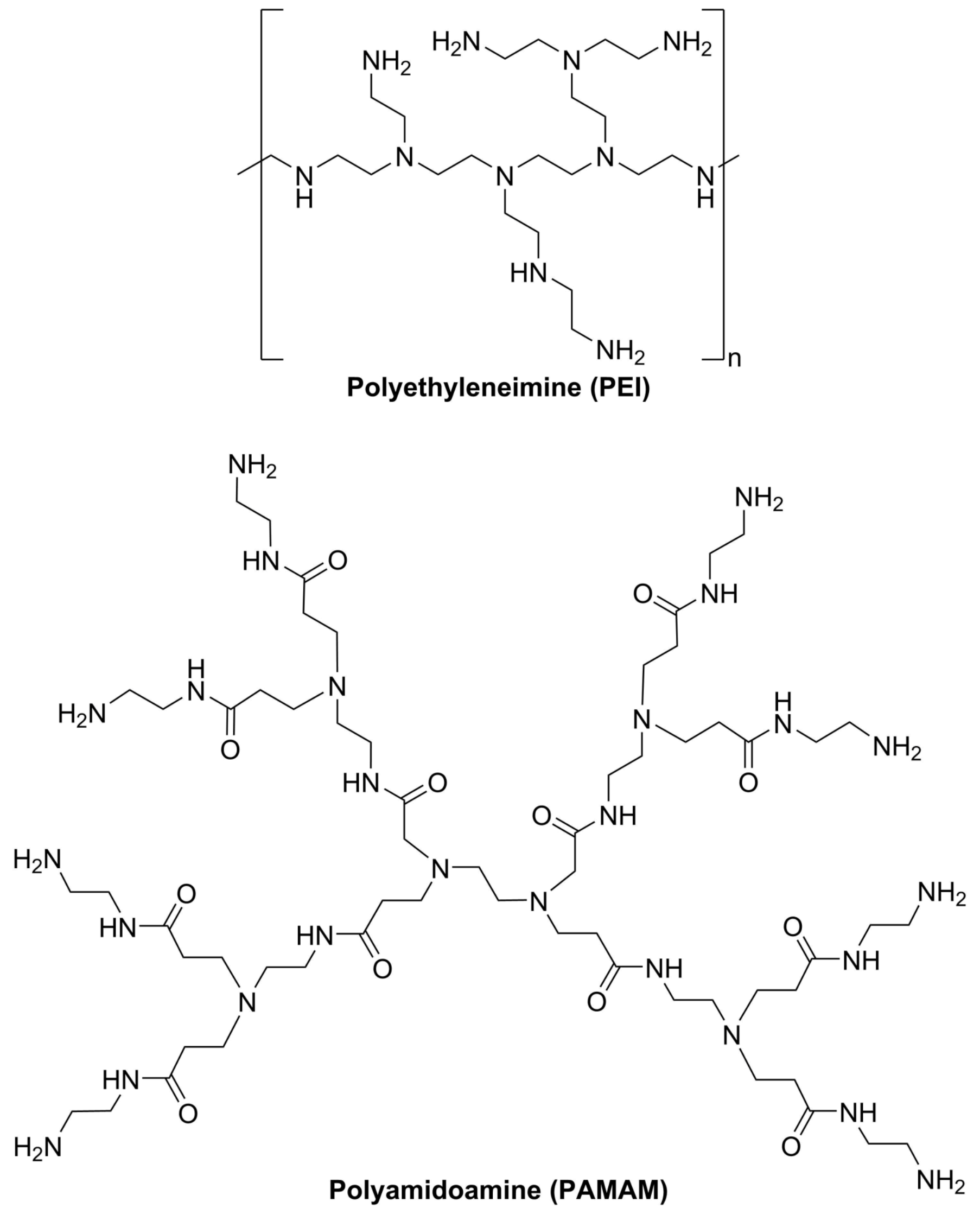

Fig. (1). Examples of the chemical structures of derivatives of polyethyleneimine (PEI) or polyamidoamine (PAMAM) dendrimer. 

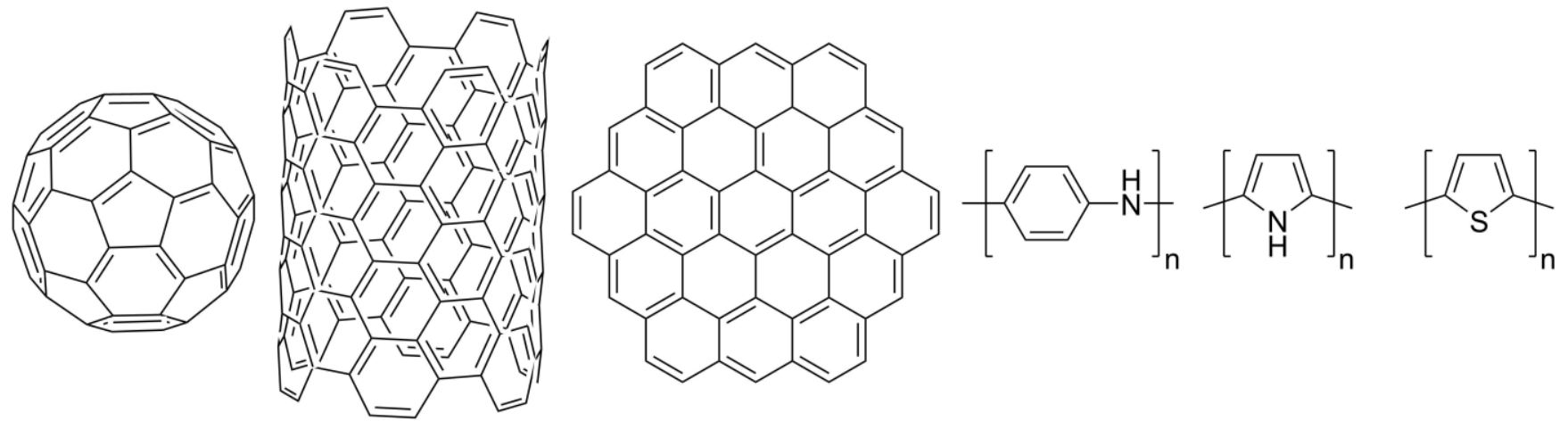

\section{Bucky ball}

Carbon nanotube

Graphene

Polyaniline Polypyrrole Polythiophene

Fig. (2). Examples of the chemical structures of derivatives of fullerenes (bucky balls or nanotubes), graphene, or conjugated polymers (e.g. polyaniline, polypyrrole or polythiophene). 

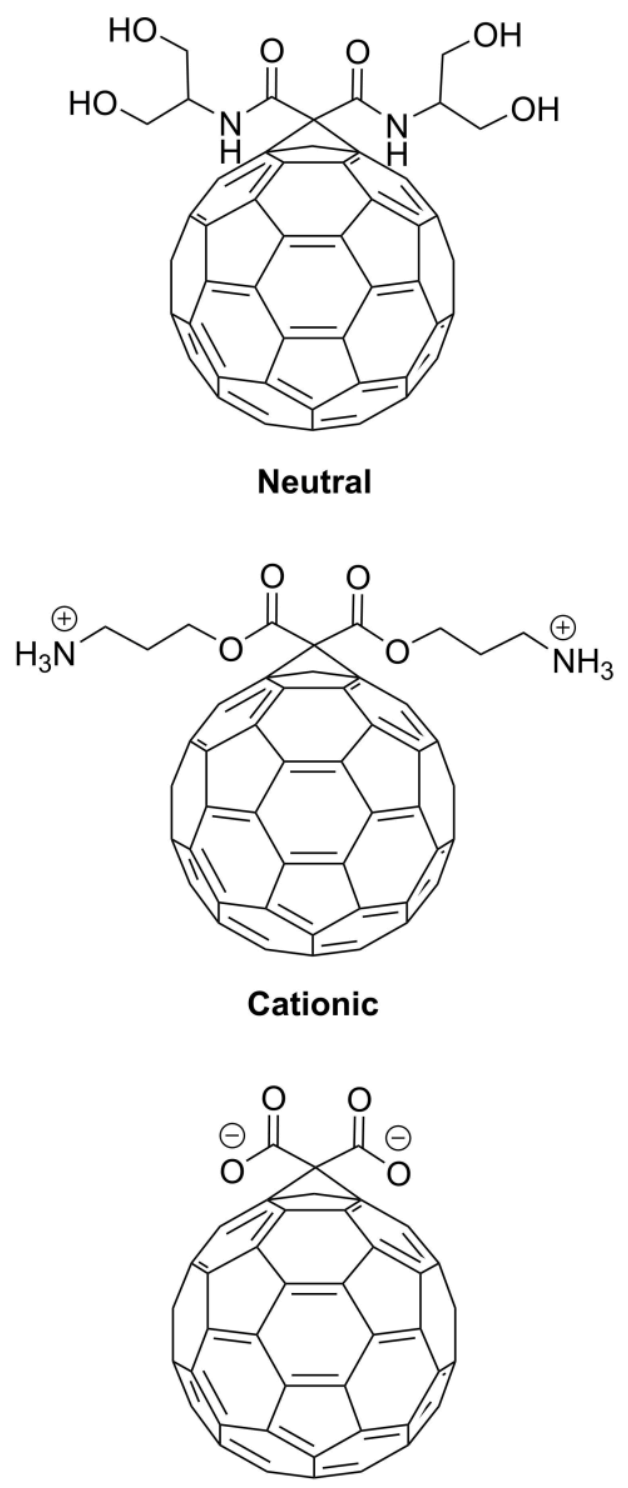

Anionic

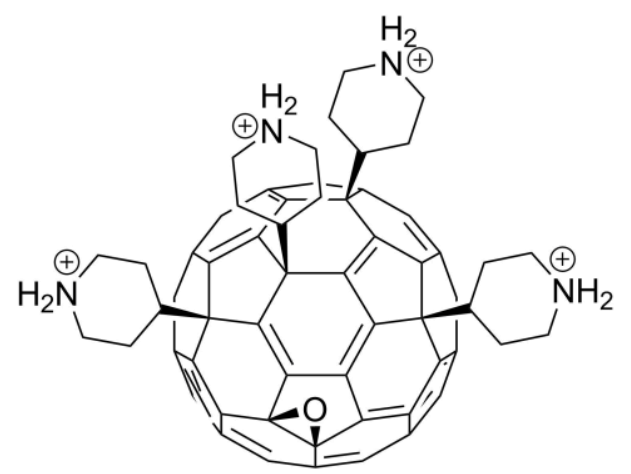

\section{Tetra(piperazino)fullerene epoxide}

Fig. (3). Examples of the chemical structures of neutral, cationic, anionic and tetra(piperazino)fullerene epoxide derivatives of bucky balls. 
A

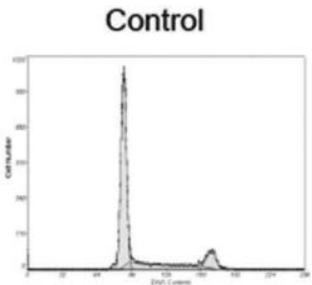

B
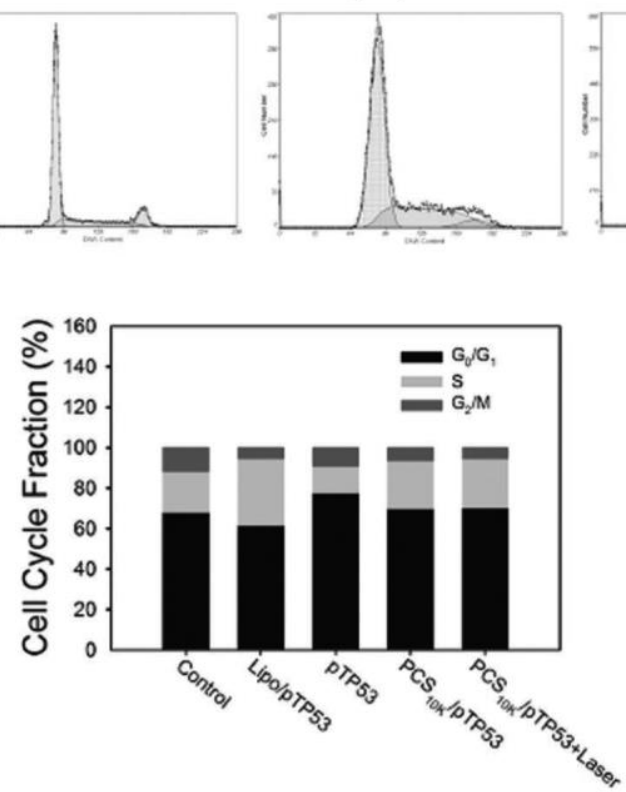

pTP53

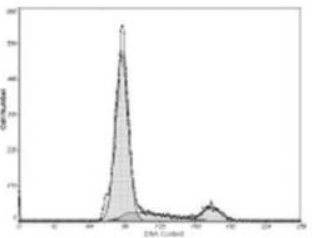

C

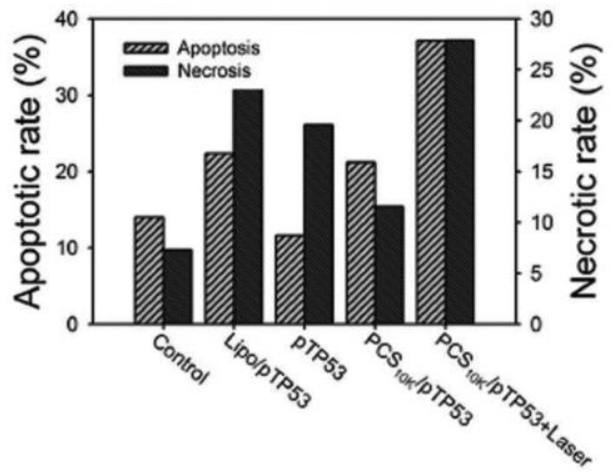

D

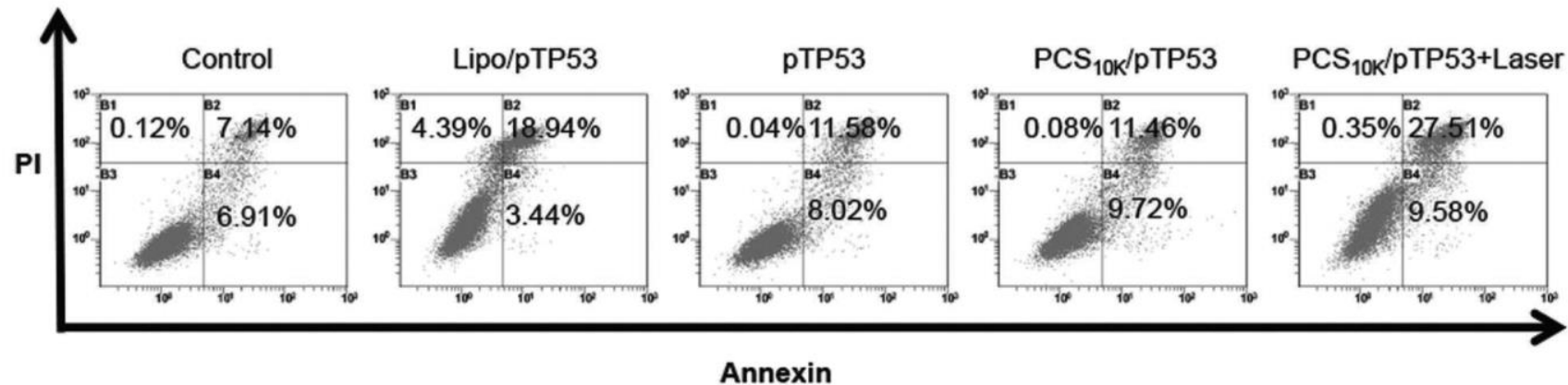

E

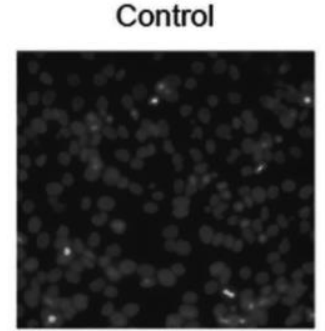

Lipo/pTP53

pTP53
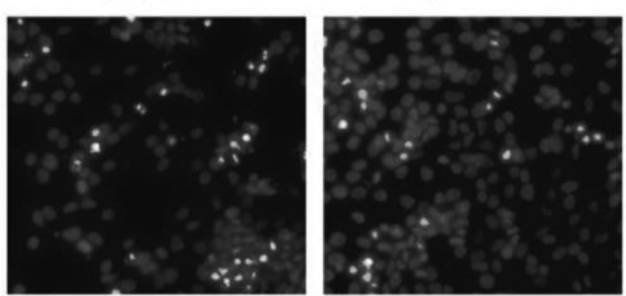

PCS $_{10 \kappa} / \mathrm{pTP53}$

PCS $_{10 K} /$ pTP53+Laser
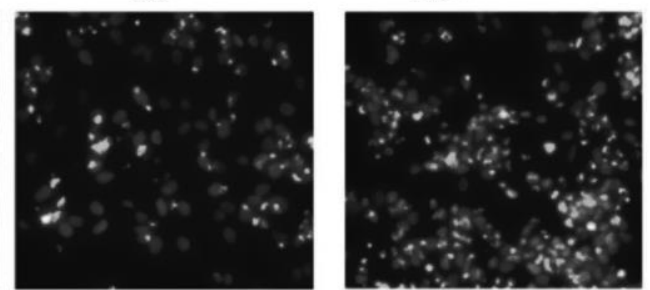

Fig. (4). Cell cycle fraction and apoptosis assay after pTP53 transfection in HeLa cells. A) Histograms and B) graph bar of cell cycle in the G0/G1, S, and G2/M population. Annexin V-FITC/PI co-staining assay by D) FCM and C) graph bar for apoptosis and necrosis rates. E) Nuclei fragment by Hoechst 33342 staining in HeLa cells. This figure is reproduced from reference 113. Reprinted by permission of John Wiley \& Sons, Inc. 
A

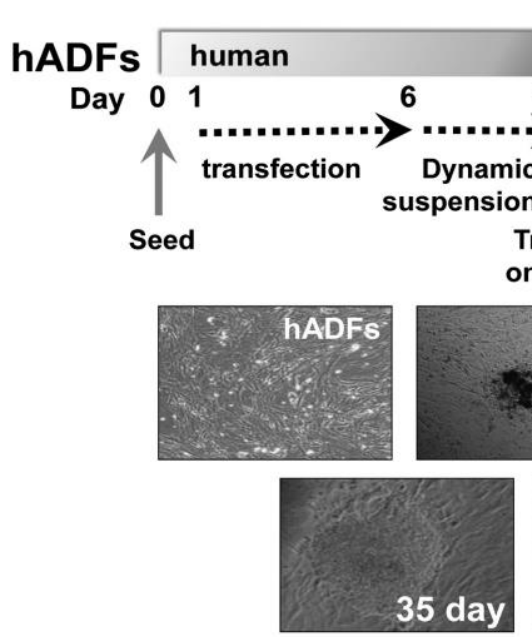

On feeder

B

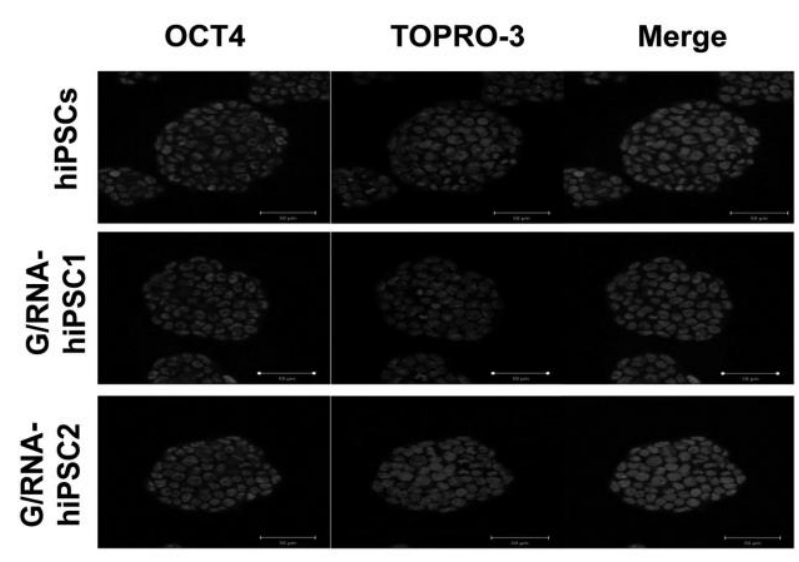

C

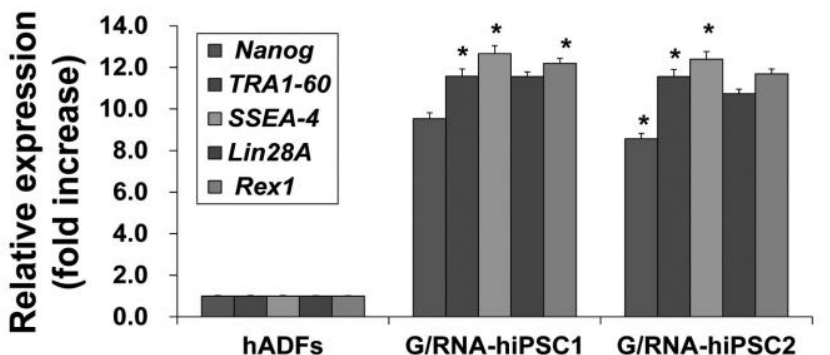

D

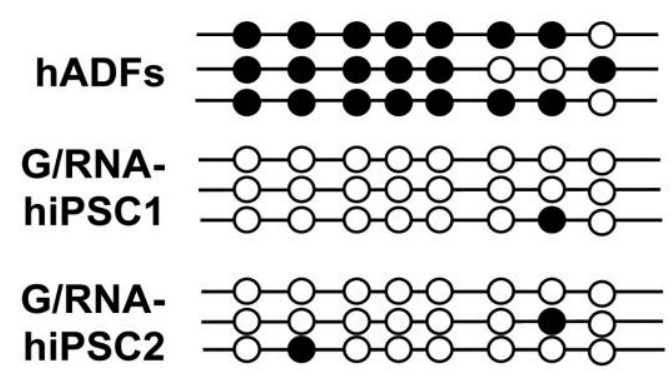

Fig. (5). GO-PEI-RNA-mediated generation of iPSCs (G/RNA-iPSCs) from ADFs. (A) Upper panel; a schematic diagram of the procedure for the preparation of hiPSCs by means of GO-PEI-mediated RNA delivery into hADFs. Lower panel; bright-field images of G/RNA-hiPSCs derived from hADFs; the former formed early iPSC-like colonies (day 18 for hiPSCs), and mature iPSC clones appeared after mechanical picking (day 24 for hiPSCs). (B) Immunocytochemical analysis OCT4 expression in G/RNA-hiPSCs. The nuclei were stained with TOPRO-3. Scale bar: $50 \mu \mathrm{m}$. (C) Quantitative real-time RTPCR analysis of the expression of endogenous pluripotency markers. Expression of the stemness markers such as SSEA-4, Lin28A, Rex1, Nanog, or TRA 160 , was analyzed in hADFs. The housekeeping gene Gapdh was used as a loading control; *p < 0.05 . (D) Bisulfite genomic sequencing of human Nanog promoter region. Open and closed circles indicate unmethylated and methylated $\mathrm{CpG}$ dinucleotides, respectively. Three representative sequenced subclones from hADFs and from the above-mentioned iPSC clones are shown. This figure is reproduced from reference 141. Reprinted by permission of Elsevier. 


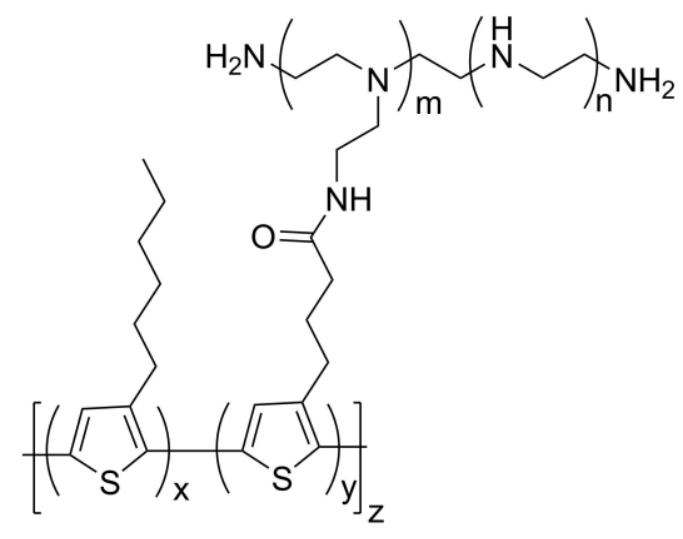

A

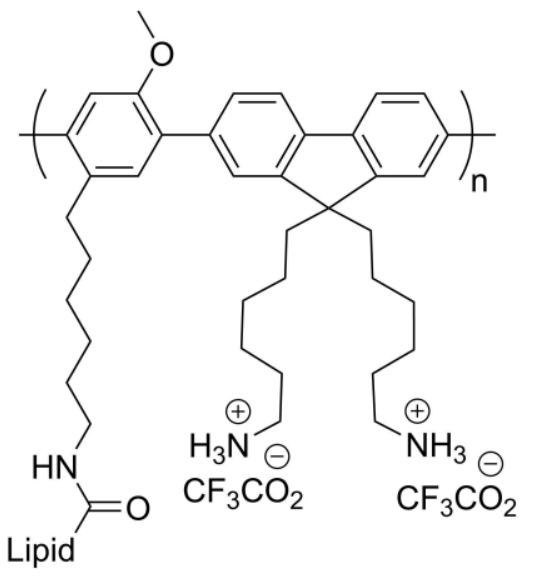

B

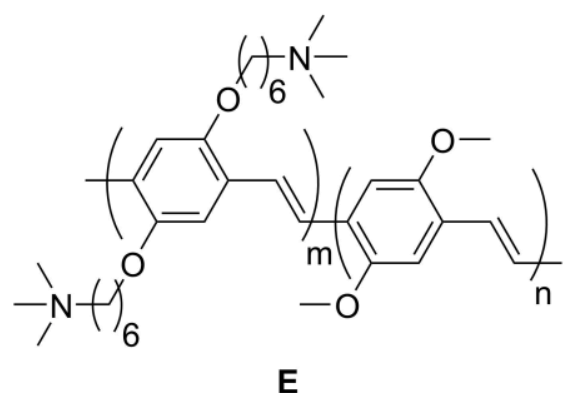

E

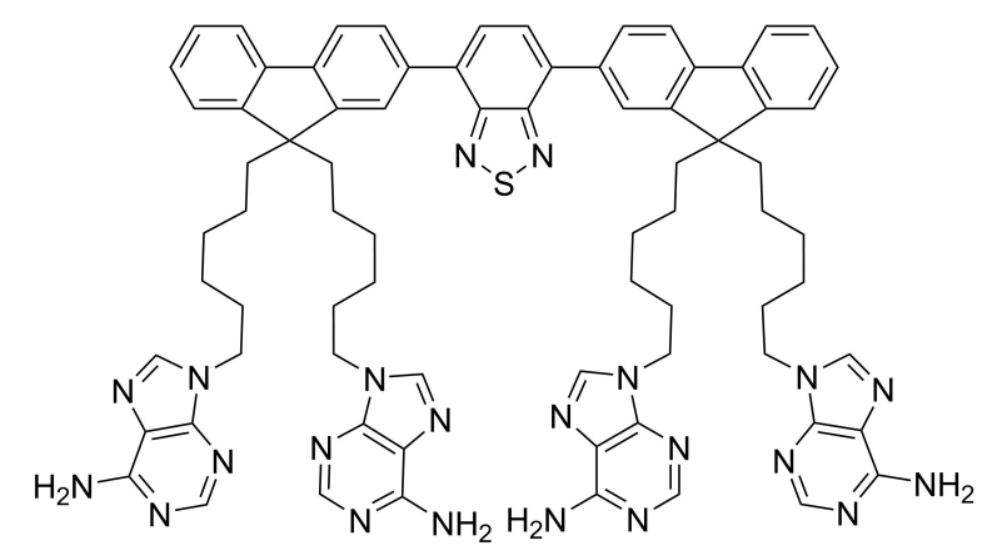

C

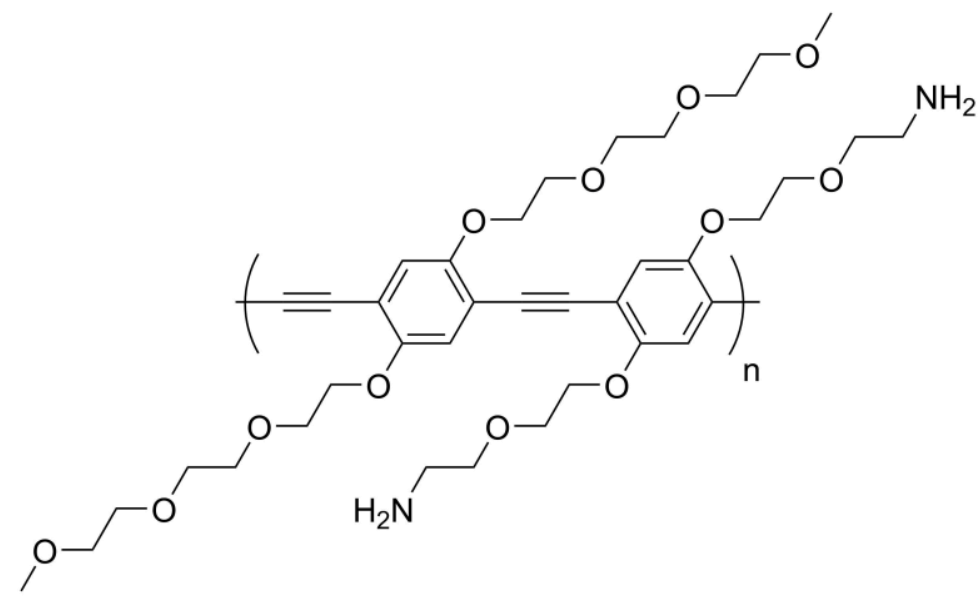

D

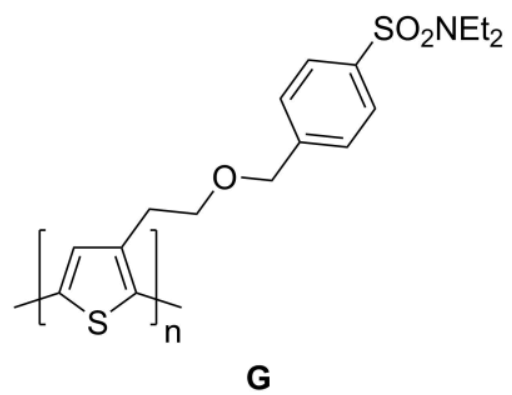

$$
[\mathrm{OLC}
$$

Fig. (6). Examples of the chemical structures of conjugated polymers. 


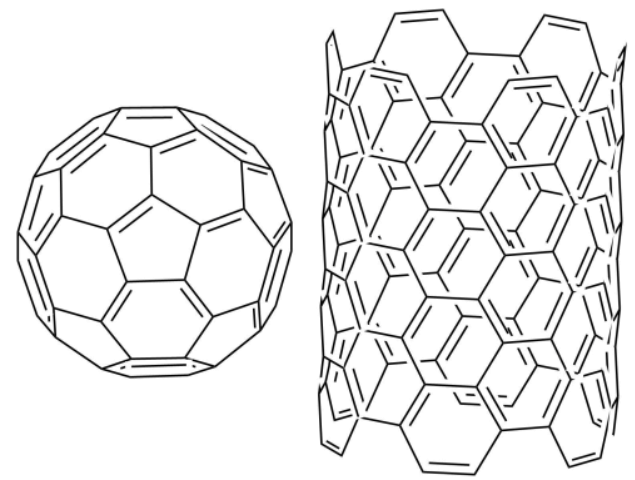

Bucky ball

Carbon nanotube

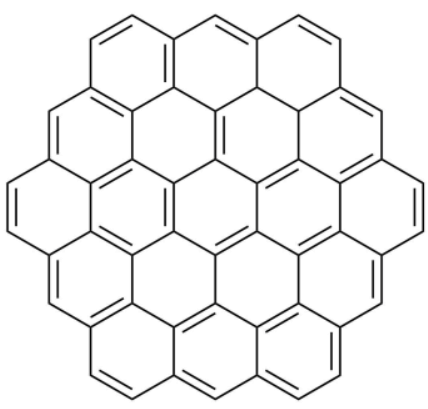<smiles>[R]c1cc(C)sc1C(C)(C)C</smiles><smiles>[R]C1c2cc(C(C)(C)C)sc2-c2sc(C(C)(C)C)cc21</smiles>

Polythiophene Polycyclopentadithiophene

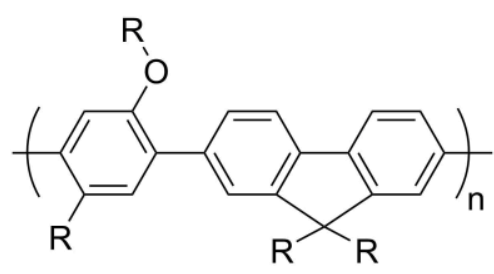

Poly(fluorenylene phenylene)<smiles>[R]Oc1cc(C#CC(C)C)c(O[R])cc1C#Cc1cc(O[R])c(C(C)(C)C)cc1O[R]</smiles>

Poly(phenylene ethynylene)

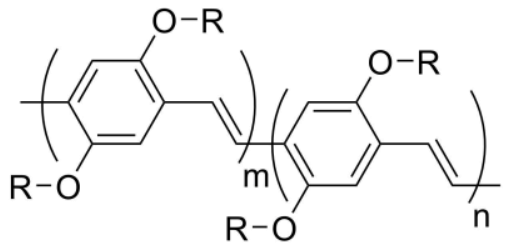

Poly( $p$-phenylene vinylene)<smiles>CCCC(NC(=O)C(CS)C(=O)O)C(=O)NCC(=O)C(CC(N)=O)NC(=O)C(N)CS</smiles>

Tumor targeting NGR peptide

Folate

Fig. (7). Examples of the chemical structures of organic electronic biomaterials and targeting units. 